\title{
MULTIPLE JOB HOLDING, SKILL DIVERSIFICATION AND MOBILITY
}

\author{
Georgios A. Panos*, Konstantinos Pouliakas**, and Alexandros Zangelidis***
}

\begin{abstract}
The inter-related dynamics of dual job-holding, human capital, occupational choice and mobility are investigated, using a panel sample (1991-2005) of UK employees from the BHPS. The evidence suggests that individuals may be using multiple job-holding as a conduit for obtaining new skills and expertise and as a stepping stone to new careers, also involving self-employment. Individuals doing a different secondary job than their primary occupation are more likely to switch to a new primary job in the next year, and a job that is different than their current primary employment. The results show that there are human capital spill-over effects between primary and secondary employment.
\end{abstract}

\section{Keywords}

Moonlighting, Occupational Choice, Human Capital, Mobility.

\section{JEL Classification Codes:}

$\mathrm{J} 22, \mathrm{~J} 24, \mathrm{~J} 62$

*Georgios A. Panos: Economics Division, Stirling Management School, University of Stirling. Cottrell Building, Room 3B79, Stirling FK9 4LA, United Kingdom. E-mail: georgios.panos@stir.ac.uk

**Konstantinos Pouliakas: Centre for the European Labour Market Research, University of Aberdeen Business School and Centre for the European Labour Market Research. Room EW S53, Edward Wright Building, Dunbar Street, Aberdeen AB24 3QY, United Kingdom. E-mail: kontantinos.pouliakas@gmail.com

***Alexandros Zangelidis: Department of Economics, University of Aberdeen Business School and Centre for the European Labour Market Research. Edward Wright Building, Dunbar Street, Aberdeen AB24 3QY, United Kingdom. E-mail: a.zangelidis@abdn.ac.uk

The authors would like to thank the Editor, two anonymous referees, seminar participants, and Dr. Francesco Renna for useful comments. The usual disclaimer applies. 


\section{Multiple Job Holding, Skill Diversification, and Mobility}

\section{Introduction}

The shift to greater labour market flexibility in recent years (Harrison, 1998) has led to lowering employer-employee loyalty, rising unemployment risk and far shorter job durations compared to the past (OECD, 1997; Gregg and Wadsworth, 1995; 1999). In the face of these changes, the need on behalf of individuals to seek for alternative ways of ensuring employment security and a continuous and higher income stream has become paramount. In addition, with rapid technological changes requiring continuous skills updating and lifelong learning, occupational mobility has come to command a higher return in modern job markets (Gregg and Wadsworth, 1996; European Commission, 2002; EurActiv, 2010). In coping with the above volatility, a large number of workers have thus been required to foster an active strategy of multiple job-holding or moonlighting ${ }^{\mathrm{i}}$ (Bell et al., 1997; Farber, 1998; Neumark, 2000).

The interest in such active strategies becomes higher in light of the recent developments in the global labour markets. The 2008 financial crisis, its follow-up recessions and the austerity measures introduced have immense disruptive consequences for the labour markets of Europe ${ }^{\mathrm{ii}}$, with recent figures sketching a gloomy picture for the UK labour market (Trades Union Congress, 2012). Unemployment rate for the $4^{\text {th }}$ trimester of 2012 has risen to $8.4 \%$, a record high since 1995 , with 2.67 million people looking for a job. Furthermore, there is a notable increase in the prevalence of part-time jobs and other atypical employment. Part-time jobs, for the same period of time, rose by 59,000 while full-time jobs fell by 50,000. In addition, temporary employment grew by 28,000 and involuntary temporary workers increased by 11,000 . The competition in the labour market is also quite intense with an average of roughly 6 unemployment people per job vacancy, and in almost a quarter of all Local Authorities with at least 10 people chasing every vacancy.

Given fewer long-term and more short-term jobs available in the labour market than experienced in earlier periods, flexible employment practices and the increased incidence of part-time employment have repercussions on job insecurity. These marked changes imply that job mobility has become more frequent while work has become less stable and secure, which in turn create a high-turnover labour market. The rise in atypical and precarious work patterns has created new poverty risks amongst the employed population. 
Multiple job-holding can act as a means of tackling financial constraints, ensuring uninterrupted employment spells and as a conduit for further career progression via the accumulation of necessary occupational expertise. The phenomenon of moonlighting has become an important characteristic of the British labour market during the time period of exacerbating labour market flexibility. Second job-holding has seen an upwards movement from around 6\% in 1991, and has remained on a high level between 1995-1999, with Böheim and Taylor (2004) reporting that moonlighting rates were about $8-10 \%$ in the period $1991-1998$, before decreasing again to about $7 \%$ in 2001 . An examination of the employment data over recent years suggests that since 1995 more than 1.2 million people in the UK have held multiple jobs (Simic and Sethi, 2002). Importantly, the number of people holding second jobs increased by 68\% between 1984 and 2001, a disproportionate rise compared to the increase in the number of people in employment over the same period of $18 \%$. In addition, British women more often hold a second job than British men, with the difference in participation rates being stable over time.

Despite the prevalence of moonlighting as another facet of atypical employment, the issue remains fairly under-researched with most available studies focusing exclusively on the determinants of the decision to moonlight (Perlman, 1966; Bell et al., 1997; Conway and Kimmel, 1998; Böheim and Taylor, 2004; Dickey and Theodossiou, 2006; Renna and Oaxaca, 2006; Wu et al. 2009). However, with the notable exception of Paxson and Sicherman (1996), the literature has been surprisingly silent with respect to the important role of multiple job-holding as facilitator of skills accumulation and as a determinant of the job/occupational transition process.

Moonlighting may be an important conduit of acquisition of new skills or of gaining experience in alternative occupations. Taking up a second job may enable individuals to eradicate any information asymmetry about new occupations, to gain relevant training or acquire new credentials that may foster subsequent occupational mobility. A close examination of the links between occupational experience, the incidence of moonlighting and job/occupational mobility is thus crucial not only for a fuller understanding of individual income growth and career progression but for the purposes of future labour market policy design as well.

The aim of this study is to examine the links between multiple job-holding and job and occupational mobility using a panel sample of male employees observed over 15 years (1991-2005) in the UK. The empirical strategy benefits from techniques that take into consideration the dynamic character of moonlighting and simultaneously allow for individual-specific effects in outcome 
equations of occupational choice, defined over non-random sub-populations of moonlighters and job-movers. The evidence suggests that non-transferable occupation-specific experience and financial constraints are contributing factors towards the selection of different occupations in the primary and secondary jobs by individuals who decide to moonlight. When examining job transitions in comparison to staying in the same job, moonlighters are twice as likely to move into self-employment in the next year and 35 percent more likely to transition into a new job with a new employer, compared to non-moonlighters. They are 17 percent less likely to become unemployed or inactive. Serial moonlighters are 25 percent less likely to get a new paid primary job in the next year (compared to temporary moonlighters). Nonetheless, individuals who switch to a different

occupation in their second job, relative to their first one, are more likely to eventually be occupationally mobile in their primary job in the future. They are also more likely to transition to a different occupational category in their next primary occupation, either in self-employment or in new paid employment.

The structure of the remainder of the paper is as follows. Section 2 provides a brief review of the available literature on the economics of multiple job-holding, drawing out any implications for job and occupational mobility. Section 3 provides a theoretical framework on how moonlighting is related to subsequent occupational mobility, while Section 4 describes the data, and Section 5 outlines the empirical strategy. Section 6 discusses the main empirical results and, finally, Section 7 concludes.

\section{Literature Review}

The literature on multiple job-holding has identified four main potential motives behind moonlighting activities (Böheim and Taylor, 2004; Wu et al., 2009). The early empirical research focuses primarily on the "hours constraints" motive and suggests that the predominant explanation for multiple job-holding is financial need, i.e. multiple-job holding is used as a survival strategy for low income households. According to the standard labour-leisure model, employees may be hours constrained, i.e. willing to work more but not being offered the chance to do so in their primary occupation (Perlman, 1966). As the willingness to work more hours is related to the provision of low or insufficient wages in the first job, this is also often referred to as the financial motive. A number of empirical studies have found an association between the level of a worker's earnings and the propensity to moonlight, showing that as the level of earnings in the primary job rises the 
incidence of multiple job-holding declines (Hamel, 1967; Guthrie, 1969; Shisko and Rostker, 1976; Krishnan, 1990). Böheim and Taylor (2004) also find evidence that a permanent contract reduces the chances of holding a second job, suggesting an association between job security and moonlighting. However, in a recent study Robinson and Wadsworth (2007) fail to find that the introduction of the minimum wage in the UK had any significant impact on the decision to moonlight.

In addition, employees may choose to find a second job in order to smooth their consumption, or as an alternative to precautionary savings, even if they are not experiencing immediate negative financial shocks (Guariglia and Kim, 2004). Multiple job-holding can therefore be seen also as a self-insurance mechanism that individuals can use to protect themselves in the presence of fluctuating earnings from the first job. If the second job offers sufficient financial protection, then it could attenuate to some extent the need of precautionary savings. Furthermore, individuals might derive different sources of satisfaction from the first and the second job. In other words, job heterogeneity might provide a motivation to moonlight on its own, such as singing in a band during the evening (Böheim and Taylor, 2004). This is the so-called beterogeneity motive (Kimmel and Conway, 2001; Renna and Oaxaca, 2006).

Apart from financial constraints, the literature has identified some additional motives for moonlighting. Heineck and Schwarze (2004) provide evidence that workers may take up a second job for other monetary benefits, acquisition of new skills or to gain experience in alternative occupations. The above arguments imply that apart from securing a continuous income stream and hedging against the risk of primary job loss, individuals may choose to take up a second job to learn about new occupations, to gain training or new credentials, to engage in activities of interest to them which provide satisfaction not received from the primary job, or to maintain flexible work schedules (e.g. a woman who requires childcare may take up two part-time jobs).

Examining the motivation for moonlighting, a large part of the literature favours the "hours constraints" explanation, particularly for the developed world. Little evidence has been presented on the view of multiple job-holding as a hedging strategy. Bell et al. (1997) find little evidence of behaviour of this type in the UK. They suggest that since moonlighting is more of a persistent/permanent phenomenon, this constitutes evidence in favour of the job heterogeneity explanation. In contrast, evidence from transition economies suggests that dual job-holding is more likely to be transitory and correlated with future job mobility. Guariglia \& Kim (2006) find that 
moonlighting in Russia is transitory and is generally associated with career shifts, often tending towards self-employment. This finding is in agreement with the view of the secondary labour market or the informal sector acting as a potential effective incubator for setting up new self-employed businesses, by fostering the development of new human capital (Levenson and Maloney, 1998; Demirgüc-Kunt et al., 2011; 2013).

The literature also highlights some other interesting patterns governing the moonlighting phenomenon. Alden (1971) finds a higher incidence of multiple job-holding in the rural regions of the UK. He also shows that self-employment is the predominant form of employment in a secondary job. Lundberg (1995) investigates moonlighting in the context of a job with amenities and argues that multiple job-holding can be explained by individuals having some emotional or other attachment to a specific sector or job that would lead them to turn down offers of higher earnings in other sectors. Krishnan (1990) explores how a husband's decision to moonlight is affected by his wife's decision to work, and finds that increased participation by wives deters multiple job-holding. Kimmel and Powell (1999) find that gender and marital status also appear to affect the decision of multiple job-holding, with women, those who are never married and young individuals more likely to take up second jobs. Alden and Spooner (1982) highlight gender differences in the preferences over the type of second job, with females tending to be paid employees, as opposed to men who are mostly self-employed in their second job. In contrast, Averett (2001) finds no substantive differences in the factors that lead men and women to moonlight.

\section{Moonlighting and Occupational Skills}

Recent works in the skill portfolio literature provide evidence for the importance of skills that are acquired via experience and can be applied to different settings. Human capital accumulates at the firm level through education, learning-by-doing and learning-by interacting, but may also be acquired externally (Robinson, 2010). Lazear's (2009) skill-weights approach assumes that all skills are general in nature but the combination of single skills varies from firm to firm. Thus, specificity can be entailed in any type of occupational training, as only the combination of single skills makes them specific. Acemoglou and Autor (2011) emphasize that the trends in modern labour markets require the distinction between skills and tasks. A task is a unit of work activity that produces output, while a skill is a workers endowment of capabilities for performing various tasks. The distinction becomes 
particularly relevant when workers of a given skill level can perform a variety of tasks and change the set of tasks that they perform in response to changes in labour market conditions and technology (Robinson, 2010).

Dual job-holding can be seen as a skill acquisition or even a specialization devise, improving expected income and at the same time protecting workers from a greater down side risk of not locating the more desired employment opportunity in a bad draw. The return to investment in a particular skill is increasing in its subsequent rate of utilization, if investment costs are independent of how acquired skills are employed (Rosen, 1983). Moonlighters can be thought to be preparing for a job transition, acquiring the skills that match the existing skill portfolio of the next occupation. Indeed, labour mobility is often regarded as a key mechanism through which knowledge diffuses, and the occupational productivity profile can be expected to vary between different jobs.

In an interesting unifying framework, Paxson and Sicherman (1996) introduce a stochastic dynamic model where the decisions to take a second job and change primary job are taken simultaneously. According to the authors, the "hours constraints" explanation can lead to a dynamic process of moonlighting and job mobility. Workers who want to work more search for a portfolio of jobs that provide desirable bundles of characteristics. They may then use dual job-holding to learn about new occupations or to gain training. Moonlighting can thus facilitate the process of transition to a different occupation.

As shown by Shaw (1987), occupational change occurs when there is a positive difference between the present value of the current and an alternative occupational pathway. She illustrates that the degree of transferability of skills across occupations is an important determinant of occupational choice, with a higher degree of transferability being associated with a greater probability of individuals moving to another job. This is because the immediate income loss that individuals will experience when moving from occupation $i$ (primary job at time $t-1$ ) to occupation $j$ (subsequent primary job at time $t$ ) will be smaller, as expressed by the condition:

$$
\Delta=\gamma^{i j} C^{i}-C^{i}=\left(\gamma^{i j}-1\right) C^{i}
$$

where, $\gamma^{i j}$ is the proportion of investment in occupation $i$ which is transferred in occupation $j$, and $C^{i}$ is the accumulated human capital specific to occupation $i$. Extending Shaw's framework to allow for individuals to engage in secondary job-holding, similar conditions for the lost occupational skills of the past investments can be derived as shown below: 


$$
\begin{gathered}
\Delta_{1}=\left(1-\gamma^{i j}\right) C^{i} \\
\Delta_{2}=\left(1-\gamma^{k j}\right) C^{k}=\left(1-\gamma^{k j}\right)\left(c^{k}+\gamma^{i k} C^{i}\right)
\end{gathered}
$$

where, equation 2 refers to people who do the same occupation ( $($ ) in both their primary and secondary job and equation 3 to individuals who are in a different occupation $(k)$ in their second job relative to their primary job $(i)^{i i i}$. As above, $\gamma^{k j}$ and $\gamma^{i k}$ refer to the proportion of investment in occupation $k(i)$ which is transferred in occupation $j(k)$, respectively. In addition, $C^{k}$ is the accumulated human capital specific to occupation $k$, which is defined as the sum of the current investment in occupational skills $k\left(c^{k}\right)$ and the proportion of occupational skills $i$ that are transferable to occupation $k\left(\gamma^{i k} C^{i}\right)$.

Comparing equations (2) and (3), it is evident that the human capital loss when deciding to do a different occupation in the second job relative to the primary one will be smaller than the associated loss for those individuals who do not diversity their occupational skills portfolio ${ }^{\text {iv }}$, when:

$$
\gamma^{k j}>\gamma^{i j} \Rightarrow \Delta_{1}>\Delta_{2}
$$

This condition leads to the following proposition, which is empirically explored in the next sections: PROPOSITION: Diversiffing occupational skills portfolio in the second job, relative to the current primary job, increases the probability of moving to a new primary occupation, when associated with greater transferability of skills.

\section{The Data}

This study uses fifteen waves of the British Household Panel Survey (BHPS, 1991-2005) ${ }^{\mathrm{v}}$ to examine the links between occupational experience, multiple job-holding, job mobility and occupational choice. The BHPS is a nationally representative household survey providing rich information on individual demographic, socioeconomic and work-related characteristics. Importantly, it identifies individuals who hold more than one job by asking "Do you earn any money from (a second job) odd jobs or from work, that you might do from time to time (apart from your main job)?"

Figure 1 plots rates of dual job-holding by year vis-à-vis the official rates of unemployment, measured both in terms of benefit claimant rates per government region and local unemployment 
rates. The figure verifies that women are more likely to hold multiple jobs than men (by almost two percentage points). The male rates are between $6.5 \%$ and $10.5 \%$, increasing in the first half of the panel and reaching a maximum in 1997. The trend declines after that year, reaching a figure close to $6.5 \%$ by 2005. Echoing the evidence on the pro-cyclicality of moonlighting in the U.S (Partridge, 2002; Amuedo-Dorantes and Kimmel, 2009), the BHPS dual job-holding line also seems to parallel the unemployment line quite closely, with a rising trend until 1997 that is reversed thereafter.

\section{[Insert Figure 1 about here]}

The empirical analysis of the paper employs an unbalanced sample of males in paid employment, aged between 18 and 60 at the time of the interview. The reason why the male sample is considered is to facilitate the examination of a homogeneous group of workers. It is well documented that men and women overall exhibit quite different labour market behaviour. In particular, women's life course trajectories are much more heterogeneous than men's. Their labour supply has been found to be more elastic, not only with regard to family events such as marriage or childbirth, but also regarding changes in the wage rate and non-labour income (Blundell and MaCurdy, 1999; Evers et al., 2008). Moreover, the literature on job mobility patterns and search behaviour has highlighted significant gender differences. Women on average exhibit a lesser commitment to labour market activity, they are relatively less mobile than men (Theodossiou, 2002), and they are less likely to be engaged in on-thejob search aiming at voluntary job mobility compared to men (Parson, 1991; van Ophem, 1991; Keith and McWilliams, 1999). The primary reason for these gender differences in labour market behaviour are the societal constraints associated with women's dominant role in childcare. Hersch and Stratton (1997) show that women, especially married women, spend three times more time engaged in household activities and are substantially more prepared to quit their job for a family-related reason than men are (Keith and McWilliams, 1997; Theodossiou, 2002). Furthermore, women are more likely to undertake secondary job tasks for immediate financial reasons or due to family responsibilities (Amuedo-Dorantes and Kimmel, 2009).

An additional criterion for inclusion in the analysis is the presence of males in the sample for at least three years, which is employed in order to enable the use of dynamic models. The average statistical life in the sample is 9.7 years. Finally, in the remainder of this study, all dual job-holders with a secondary hourly wage greater than $£ 150$ or smaller than $£ 1$ are dropped, in order to exclude outliers and unpaid family workers and ensure comparability with international studies of dual job holding ${ }^{\mathrm{vi}}$. The sample is comprised of 5,583 individuals (37,209 observations). There are 2,600 spells 
of dual job-holding in the data, by 1,080 individuals. This is suggestive of the persistent nature of multiple job-holding in the U.K (Bell et al., 1997; Böheim and Taylor, 2004), as a large number of individuals are engaged in a second job for more than one year during the sample life.

Table 1 presents summary statistics for primary and secondary job characteristics in the sample. On average, $7 \%$ of the employed male sample is occupied in a paid second job. The average gross monthly salary in the primary occupation is $£ 1,340$ for an average of 39 hours of work per week. The average monthly salary in the second job appears to be $£ 231$ for an average of 6 hours per week. Both the figures for earnings and hours of work in the second job entail large standard deviations. The median hourly wage is $f_{6} 6.2$ for the primary job and $f^{7}$ for the secondary job (the earnings figures are in 1991 values, deflated using the ONS GDP deflator).

A first examination of the 1-digit Standard Occupational Classification (SOC) codes in the primary and secondary jobs suggests that the proportion of people who work as "Managers \& administrators", "Plant \& machine operatives" and in "Clerical \& secretarial occupations" in their secondary occupation is significantly lower compared to the respective groups in the primary occupation. There appears to be a higher incidence of lower-skilled occupations in the second job, such as "Associate professional \& technical", "Personal \& protective service" and "Other occupations". It is thus of great interest to examine the factors that affect the decision of individuals whether to conduct the same or different types of jobs between their primary and secondary employment.

In terms of occupational choices in the $2^{\text {nd }}$ job, the figures in Table 1 suggest that $68 \%$ of the moonlighters choose to do a different occupation than their primary job. The figure is obtained using 1-digit SOC classification codes, and the figures for different occupation in the second job using 2-digit and 3-digit codes are 79\% and 84\% respectively. 50.5\% of these dual job-holders are in paid employment in their second job, while $49.5 \%$ are in self-employment. $49.1 \%$ hold a second job for two consecutive years (serial moonlighters).

Panel B of Table 1 presents selected primary and secondary job characteristics distinguishing between the sub-samples of individuals who moonlight at a different and at the same occupation as in their primary job. Three sets of distinctions are presented, at the 1-digit, the 2-digit and the 3-digit SOC level, respectively. It is shown that individuals moonlighting in different occupation are earning less on average in their primary job. Moreover, they are working more hours in their secondary job, 
and are earning less on average. Furthermore, they are less likely to be self-employed in their secondary occupation. These patterns are consistent at all 1-, 2-, and 3-digit SOC distinctions.

\section{[Insert Table 2 about here]}

Table 2 indicates that dual job-holders are earning significantly lower (hourly or monthly) wages in their primary job. Moreover, 13.2\% of dual job-holders are found in the low-paid group, defined as those earning less than two thirds of the median earnings in the sample. The respective figure is $7.9 \%$ for those employed solely in one job. Single job-holders are also more likely to have a higher household income and are less likely to be "relatively poor" (i.e. report equivalised household income less than two thirds of the sample median). Dual job-holders are less likely to be married and to have an employed partner if married. They are younger on average and have lower labour market experience, occupational-specific experience ${ }^{\text {vii }}$ and job tenure. They work less hours on average in their primary occupation, both in terms of normal weekly hours and paid overtime. However, they are more likely to want to work more hours in that job, which is indicative of hours constraints.

A raw inspection of job transitions suggests that 3.8\% of dual job-holders switch to selfemployment as a primary job in the next year, compared to $1.9 \%$ of non-moonlighters. The difference is statistically significant at the $1 \%$ level. Similarly, $13.7 \%$ of moonlighters move to a new job with a new employer, compared to $11 \%$ of non-moonlighters, and are less likely to remain in the same position with the same employer. These patterns suggest that there is a relationship between dual job-holding and job mobility. It is important to notice, though, that the rates of transition to unemployment do not differ significantly between dual and single job-holders $(1.9 \%$ and $2.2 \%$ respectively).

In terms of occupational choices, the sample averages in Panel (C) of Table 2 suggest that those dual job-holders doing the same occupation in their primary and secondary job are more likely to be wealthier and to have higher job tenure and occupational experience. Apart from Managers and Administrators, the groups more likely to diversify between the two jobs are those in unskilled occupations in their primary jobs (i.e. clerical \& secretarial, plant and machine operatives, sales and other occupations). In the first instance, there appears to be a small positive association between the incidence of dual job holding and occupational diversification in the next year (significant at the 10\% level at the 3-digit SOC). However, occupational choice in the second job and that of the next 
occupation appear to be related, with individuals diversifying in their second job being significantly more likely to do a different job in the next year, if they transition to new employment or a new position.

\section{Statistical Methodology}

In investigating the determinants of the occupational choice at the second job, and the implications of the latter for subsequent job and occupational mobility, a number of important statistical issues arise that can be conceptualized as two distinct individual decisions. First, the analysis focuses on modeling the discrete binary choice of taking up a secondary occupation that is different from the one in the primary job. This is done in order to examine how such occupational choices are related to the various motives for moonlighting that were described in Section 2 above. Second, the interest turns to examining the potential links between the primary-secondary occupational choices of individuals at time period $t$ and their subsequent labour market mobility and occupational decisions in the next period $(t+1)$. This analysis enables the investigation of the proposition derived in section 3. For both set of issues the econometric methodology pays particular attention to the potential incidental selection problem that arises, given that in the first case the sample is comprised of dual job-holders only, whilst in the second the sample is a non-random representation of individuals who have switched jobs. The next two sections describe the statistical methodology employed in the study.

\subsection{The Profile of the Dual Job-Holder and Occupational Choice}

Following the decision to take-up multiple jobs, individuals are likely to engage in a discrete choice of whether to select a secondary occupation that is different from the one in the primary job. On the one hand, undertaking a similar occupation in a second job as in the primary one may allow individuals to benefit from the specialization that may result from the accumulation of occupationalspecific skills. This may constitute an optimal response, especially in the face of financial constraints that may be the motivating factor underlying the decision to moonlight. On the other hand, performing a secondary job that deviates from the original one may foster the building-up of a different stock of skills that may encourage the transition to a different occupation in the future.

The occupational change choice can be examined within a human capital investment framework, where individuals weight the benefits of potential earnings and non-pecuniary returns and costs of 
training and forgone earnings or wage premia associated with accumulated occupation-specific skills. The individual will invest in changing occupations only if there are net benefits. An occupational change entails a short-term financial loss (Parrado et al., 2007; Kampourov and Manovskii, 2008) related to the loss of occupation-specific human capital. However, such changes often lead to positive long-term effects when are related to career changes and shifts to occupations that offer higher or faster wage growth. Individuals' wealth can partially affect occupational mobility decisions, since given imperfect capital markets, resources for investing in oneself will not be equally accessible to all people. Wealth in this case is expected to absorb the short-term financial distress/losses related to forgone earnings and training costs.

This decision can be formally represented as follows:

$$
\begin{gathered}
o c c_{i t}^{(m)}=1\left\{\mathrm{x}_{i t}^{\prime} \theta+\alpha_{i}+u_{i t} \geq 0\right\}, \quad i=1, \ldots, \mathrm{N} ; t=2, \ldots, \mathrm{T} \\
m_{i t}=1\left\{m_{i t}^{*}=\mathrm{z}_{i t}^{\prime} \beta++\xi m_{i t-1}+\eta_{i}+\varepsilon_{i t} \geq 0\right\}
\end{gathered}
$$

where in equation (5), the main equation of interest, the dependent variable, $\operatorname{occ}^{(m)}{ }_{i t}$, is a binary variable that represents secondary job choices. We utilize three distinct choice variables, i.e. three binary variables that take the value of one for those who do an secondary occupation that is different from the one in their primary job (based on 1-digit, 2-digit and 3-digit SOC level respectively), and zero otherwise. $o c c^{(m)}{ }_{i t}$ is assumed to depend on a vector of regressors, $\boldsymbol{x}$, and on a composite error term, $v_{i}=\alpha_{i}+u_{i t}$, where $\alpha_{i}$ is a term capturing unobserved individualspecific effects with $E\left(\alpha_{i} \mid x_{i t}\right) \neq 0$ and $u_{i t}$ is a random error term with $E\left(u_{i t} \mid x_{i t}\right)=0$. Importantly, $\operatorname{occ}^{(m)}{ }_{i t}$ is only observed if $m_{i t}=1$, where $m_{i t}$ is an indicator (selection) variable for individual $i$ being a dual job-holder at time period $t, \boldsymbol{Z}$ is a vector of explanatory variables $(\boldsymbol{z}>\boldsymbol{x}$ for identification purposes) and $c_{i t}=\eta_{i}+\epsilon_{i t}$ is a composite error term with $\varepsilon_{i t} \sim \operatorname{iidN}\left(0, \sigma_{\varepsilon}^{2}\right)$, $E\left(\varepsilon_{i t} \mid z_{i t}\right)=0$. The time-invariant fixed effects term, $\eta_{i}$, is assumed to account for potential omitted variable bias in the model, $E\left(\eta_{i} \mid z_{i t}\right) \neq 0$, and is also responsible for serial correlation in $c_{i t}$.

Equations (5) and (6) take into account a number of important elements that are likely to characterize the economic problem that individuals face. First, the term $m_{i t-1}$ is included in equation (6) to capture the effect of state dependence which has been identified as a typical characteristic of the decision to moonlight (Bell et al., 1997; Böheim and Taylor, 2004). Second, it has been deemed necessary to account for unobserved individual heterogeneity in the form of time- 
invariant fixed effects ( $\alpha_{i}$ in equation 5 and $\eta_{i}$ in equation 6$)$, since there are important unobserved factors that may affect both the decision to moonlight and the subsequent occupational choice of a secondary job. For instance, it may be argued that less risk-averse individuals are more likely to engage in multiple job-holding, or to select a different occupational track as a secondary job choice. Third, a correction for potential sample selection bias is required in order to obtain consistent parameters in equation 5, since estimation of the main outcome equation is conditional on the potentially non-random subpopulation of those individuals who decide to moonlight (equation 6) (Heckman, 1979).

In order to address the above issues, Wooldridge (1995) and Semykina and Wooldridge (2005) have proposed a suitable Conditional Maximum Likelihood (CML) estimation procedure. Specifically, following Mundlak (1978) and Chamberlain (1984) it is initially assumed that the correlation between $\eta_{i}$ and $z_{i t}$ can be parameterized via a linear relationship, $\eta_{i}=\bar{z}_{i}^{\prime} \delta+\omega_{i}$, where $\omega_{i} \sim \operatorname{iid} N\left(0, \sigma_{\omega}^{2}\right), E\left(\omega_{i} \mid z_{i t}, \varepsilon_{i t}\right)=0$ and $\bar{z}_{i}$ are the means over the sample period of all exogenous variables. Equation (6) is therefore expressed as:

$$
m_{i t}=1\left\{\mathrm{z}_{i t}^{\prime} \beta+\xi m_{i t-1}+\bar{z}_{i}^{\prime} \delta+\omega_{i}+\varepsilon_{i t} \geq 0\right\}, \quad i=1, \ldots, \mathrm{N} ; t=2, \ldots, \mathrm{T}
$$

As argued by Chamberlain (1984), estimation of the likelihood function requires an assumption about the relationship between the initial observations, $y_{i 1}$, and $\omega_{i}$. Assuming linearity $\omega_{i}=\omega_{0}+$ $\omega_{1} y_{i 1}+\psi_{i}$, Wooldridge (2005) has shown that a procedure that entails the addition of the initial value, $m_{i 1}$, and the means of the time-varying exogenous regressors into the main specification (5) can lead to consistent estimation parameters: ${ }^{\text {iii }}$

$$
m_{i t}=1\left\{\mathrm{z}_{i t}^{\prime} \beta+\xi m_{i t-1}+\bar{z}_{i}^{\prime} \delta+\omega_{0}+\omega_{1} m_{i 1}+\psi_{i}+\varepsilon_{i t} \geq 0\right\}, \quad i=1, \ldots, \mathrm{N} ; t=2, \ldots, \mathrm{T}
$$

Wooldridge postulates further that since the errors in the selection equation, $\varpi_{i t}=\omega_{0}+\psi_{i}+\varepsilon_{i t}$, and $u_{i t}$ are independent of $\bar{z}_{i}$ and $\varpi_{i t} \sim N\left(0, \sigma_{\varrho}^{2}\right)$ and $E\left(u_{i t} \mid \bar{z}_{i}, \varpi_{i t}\right)=\rho_{t} \varpi_{i t}$, the conditional expectation of $\alpha_{i}$ can be expressed as a linear function of $\bar{z}_{i}$ and $\varpi_{i t}$ as follows:

$$
E\left(\alpha_{i} \mid \bar{z}_{i}, \varpi_{i}\right)=\bar{z}_{i} \vartheta+\left(\phi_{t}+\rho_{t}\right) E\left(\varpi_{i t} \mid \bar{z}_{i}, m_{i t}=1\right)
$$

which results in the following model of the outcome equation:

$$
\text { occ }^{(m)}{ }_{i t}=1\left\{\mathrm{x}_{i t}^{\prime} \theta+\bar{z}_{i} \vartheta+l_{t} \lambda\left(H_{i t}\right)+u_{i t} \geq 0\right\}
$$


where $l_{t}=\left(\phi_{t}+\rho_{t}\right), H_{i t}=\left(\mathrm{z}_{i t}^{\prime} \beta+\xi m_{i t-1}+\bar{z}_{i}^{\prime} \delta+\omega_{1} m_{i 1}\right)$ and $\lambda\left(H_{i t}\right)=\frac{\varphi\left(H_{i t}\right)}{\Phi\left(H_{i t}\right)}$ is the inverse Mill's ratio with $\varphi($.$) denoting the standard normal density and \Phi($.$) is the standard cumulative$ normal distribution function.

For the estimation of equation (10), Wooldridge recommends that separate probit regressions are estimated on the selection equation (8) per each year $t$ from which $\lambda\left(H_{i t}\right)$ is obtained (correcting the standard errors for robustness). In the second step, equation (10) may then be consistently estimated by a pooled OLS regression (with bootstrapped standard errors). ${ }^{\text {ix }}$

\subsection{Dual Job-Holding, Job Mobility and Occupational Choice in the New Job}

The choice of primary and secondary job is likely to significantly affect the mobility of individuals via the accumulation of occupation-specific skills that it entails. As shown by Shaw (1987), in a world of perfect information the probability of employer or occupational change increases with the transferability of human capital. Furthermore, imperfect knowledge of the "match" between one's abilities and the job requirements is likely to facilitate a move to an unrelated occupation. An additional job, especially one that is distinct to the primary occupation, is therefore likely to enhance the prospect of labour market mobility, by affecting the available stock of occupation-specific skills and/or by alleviating the uncertainty regarding the worker-job match.

The focus of interest therefore now turns to examining how the occupational diversification between primary and secondary jobs at time period $t$ affects the subsequent labour market decisions of individuals in the next period $(t+1)$, both in terms of their mobility to a new primary job and with respect to the occupational choice made. A similar framework to the one used in Section 5.1 is employed:

$$
\begin{gathered}
\operatorname{occ}_{i(t+1)}^{(p)}=1\left\{\mathrm{x}_{i t}^{\prime} \theta+\alpha_{i}+u_{i t} \geq 0\right\}, \quad i=1, \ldots, \mathrm{N} ; t=1, \ldots, \mathrm{T}-1 \\
p_{i(t+1)}=1\left\{p_{i(t+1)}^{*}=\mathrm{z}_{i t}^{\prime} \beta+\eta_{i}+\varepsilon_{i t} \geq 0\right\}
\end{gathered}
$$

where $\operatorname{occ}^{(p)} i(t+1)$ is now a binary variable taking the value of one if individuals in a new primary job at time $t+1$ are doing an occupation different from their primary job in the previous period $(t)$. Differences in occupations are examined at all 1-digit, 2-digit and 3-digit SOC levels. As before, an incidental truncation problem arises as this variable is only observed for those individuals who decided to change their primary employment, i.e. $p_{i(t+1)}=1$. The Wooldridge (1995) and Semykina 
and Wooldridge (2005) methodology is utilized again so that the estimation of equations (11) and (12) proceeds as follows ${ }^{x}$ :

$$
\begin{gathered}
o c c_{i(t+1)}^{(p)}=1\left\{\mathrm{x}_{i t}^{\prime} \theta+\bar{z}_{i} \vartheta+l_{t} \lambda\left(H_{i t}\right)+u_{i t} \geq 0\right\} \\
\mathrm{p}_{i(t+1)}=1\left\{\mathrm{z}_{i t}^{\prime} \beta+\bar{z}_{i}^{\prime} \delta+\psi_{i}+\varepsilon_{i t} \geq 0\right\}
\end{gathered}
$$

\section{Empirical Results}

\subsection{The Profile of the Multiple Job-Holder}

The results presented in Table 3 are based on estimation of equation (8), the selection equation identifying the likelihood of individuals engaging in multiple job-holding. Apart from the terms that account for state dependence and the initial condition (Moonlighting $((-1) \text {, Moonlighting } \text { (Year } 1)_{1}$ ), the specification controls for the local unemployment rate (by administrative region), job satisfaction, and the logarithms of equivalised household income in the year prior to the survey, labour market experience, occupation-specific experience, job tenure, weekly working hours, paid overtime hours, and number of children. Moreover, the list of explanatory variables includes dummy variables capturing whether an individual wants to work more or less hours in the primary job, marital/cohabitation status and partner's employment status, education, and occupation in the primary job (1-digit SOC codes). Finally, additional variables are included that control for private sector, permanent job, promotion prospects, and annual earnings increments in the primary job, along with dummy variables for industry, region and wave. A convenient way of interpreting the coefficients is to consider the estimated joint effect of the mean terms of the variables (Mundlak terms) and the level variables as the "permanent" effect of the regressors on the decision to hold a second job ${ }^{x i}$. The coefficients on the level of the variables represent instead the response to a "transitory" change in these variables.

Overall the results highlight some important patterns regarding the motives of the decision to moonlight. First, there is significant evidence in favour of the financial or hours-constraint motive, as it is clear that the transitory effect of individuals' household income in the last year exerts a negative effect on the probability of currently holding a second job. Furthermore, individuals who permanently prefer to work more hours in their present primary job are more likely to hold a second job compared to those who are content with their working hours. Individuals who would like to 
work less hours in their current job are less likely to moonlight. In addition, although the total number of contracted hours of work in the primary job does not affect the moonlighting decision, the number of paid overtime hours, which can act as an alternative response of individuals to financial constraints, is found to have a negative and significant effect on multiple job-holding ${ }^{x i i}$. Individuals with promotion prospects in their primary job and those who receive annual increments in their salary are also less likely to have a second job.

At a more aggregate level the positive effect of the current local unemployment level suggests that individuals respond to a negative demand shock, such as an increase in the unemployment rate, by obtaining a second job as an insurance shield against increased labour market uncertainty. Job satisfaction is found to exert a negative transitory effect on the likelihood of moonlighting, signifying that individuals who become less satisfied with their jobs are more likely to moonlight. This could be indicative of the intension to move into a new job once the opportunity arises ${ }^{\text {xiii }}$. Though no temporary effects of the variables marital status, employment status of the spouse, and number of children are found, presumably due to their low variation over time, their mean effects are statistically significant. This suggests that they exert a permanent effect on the decision to hold a second job. Single people are found to be more likely to engage in moonlighting. A greater number of children, presumably due to the increased associated financial burden, is found to exert a positive impact on the decision to hold a second job. Furthermore, educational ${ }^{\mathrm{xiv}}$ and occupational differences appear to explain very little of the variation in the decision to hold an additional job, although the evidence is indicative that lower-skilled occupations are more conducive to moonlighting. Areas in the south appear to have the highest instances of dual-job holding.

The estimated model includes controls for both the multiple job-holding status of the individuals in the previous year as well as in the year they first appeared in the sample. Both variables are estimated to have a positive and statistically significant effect on the decision to hold a second job in the current period, suggesting that the incidence of multiple job-holding contains a permanent labour market element. Given the evidence of its persistent dynamic nature, it is difficult to rationalize that multiple job-holding is a temporary individual response to financial shocks. Nonetheless, the permanency of moonlighting is consistent with previous findings of the literature that have showed that low-paid workers (who are more likely to engage in multiple job-holding) are typically trapped in a "low-pay/no pay" vicious cycle (Webb et al., 1996; Machin, 1999; Stewart, 1999; Stewart and Swaffield, 1999; Dickens, 2000; TUC, 2007). 
Finally, the significant negative permanent effect of a constructed measure of occupation-specific experience (Zangelidis, 2008a) implies that employees with a greater set of specific skills, who are likely to enjoy higher (wage) returns from a first job (Zangelidis, 2008a and 2008b; Kambourov and Manovskii, 2009a; Williams, 2009), will be less in need of performing a secondary job. Interestingly, the level effect of tenure (transitory effect) implies that as individuals gain seniority in their current employment they are more likely to hold a second job. This finding may be potentially explained by the unwillingness of individuals to search for a second job in the initial or probationary period of employment.

\section{[Insert Table 3 about here]}

\subsection{Multiple Job-Holding and Occupational Choice}

Conditional on the determinants of dual job-holding shown in Table 3, the analysis now turns to the occupational choices of those who decide to have a second job i.e. the estimation of Equation (10).

The results of linear regressions are presented in Table $4^{\mathrm{xv}}$. The list of explanatory variables is similar to that of Table 3, with the exception of the dynamic terms, in accordance to the methodology described in Section 5.1 for the occupational choice model. In addition, individuals who hold a second job for financial reasons are likely to compare the available employment opportunities they have and choose the one with the highest potential in terms of earnings capacity, in accordance with the prediction of standard models of occupational choice (e.g. Freeman, 1971; Boskin, 1974; Berger, 1988; Montmarquette et al., 2002). In order to capture this decision, a new variable in the dataset has thus been created that compares the wages that the individual is likely to receive from his current occupation with the predicted earnings from the best alternative occupation. The latter is defined as the occupation that individuals are most likely to do as part of their primary employment, besides the one that they are currently employed in (see the description in the Appendix for details). As expected, the estimated coefficient of this variable is negative and significant at the 1-digit and the 2-digit SOC level, suggesting that individuals who have higher earnings possibilities in their current occupation, relative to other viable options, are less likely to choose a different occupation in their second job.

Our three measures of occupational choice in the second job are binary variables capturing difference in occupational codes compared to the primary job, at the 1-digit, the 2-digit and the 3digit SOC level respectively ${ }^{\mathrm{xvi}}$. When occupational changes are observed at the broader more 
aggregate 1-digit level, they can be regarded as changes of great magnitude. Occupational mobility at the 1-digit level is more likely to be observed when individuals want to acquire a different set of skills and explore alternative career pathways rather than when they want to increase their labour income through a second job. In contrast, the influence of labour market conditions is expected to be more evident at the 2-digit or 3-digit level of secondary occupational choice complementarity. Therefore, individuals who moonlight for financial reasons are expected to primarily remain in the same occupation, or move to a similar occupation where they can still use their skills and expertise (using the notation from Section 3, $\gamma^{i k}$ close to one) in order to maximise their earnings capacity. Whereas, individuals who seek to expand their portfolio of skills have to bare these short-term income losses. Wealth can ease the financial pressure in this case, so affluent individuals may be more likely to explore different occupations and new career pathways than those who have more demanding financial commitments.

As discussed before, a measure of occupational-specific experience has thus been included in the regression as a control variable (Zangelidis, 2008a). The findings confirm a priori expectations, as individuals with lengthier occupational experience in their primary job are less likely to choose a different occupation in their second job. Interestingly, accumulated labour market experience is found to have the opposite (positive) effect only at the 3-digit level. One plausible explanation for the latter result may be that individuals with lengthier overall working experience have better knowledge of the labour market and better information regarding employment opportunities. Furthermore, the length of total labour market experience may be regarded as a proxy of the level of accumulated general, highly transferable, skills.

Household characteristics are important determinants of individuals' occupational choice in the second job. Specifically, married or cohabitating individuals (particularly those whose spouse is not employed) are estimated to be less likely to do a different occupation in their second job, compared to that in their primary one. This finding may be interpreted as evidence that individuals with increased financial commitments are more likely to choose as their second job an occupation that that they are familiar with, as a means of increasing their earnings capacity.

Workplace characteristics of the primary job are also found to affect the occupational choice in the second job. In addition, individuals with a low level of education, compared to those with a University degree or above, are found to be less likely to do a secondary occupation different to the one in their primary job (at the 1-digit SOC level). Finally, the majority of the individuals employed 
in occupations other than Managers and Administrators are less likely to choose a different occupation in their second job.

\section{[Insert Table 4 about here]}

Overall, the above findings imply that individuals in low-skilled jobs and/or those facing increased family commitments or financial constraints are more likely to select a similar occupation in the second job as in their primary one. This is presumably to exploit the higher earnings opportunities that their non-transferable occupational experience secures. The contrary holds for those individuals who enjoy a relative sense of financial security, who can therefore "afford" to select different occupational streams in their secondary employment that satisfy their intrinsic preferences.

\subsection{Multiple Job-Holding and Job Mobility}

Focusing on the selection equation (14) first, particular interest is paid to the following five possible labour market outcomes concerning the primary employment: (1) staying in the same job; (2) becoming self-employed; (3) getting a new salary job; (4) getting a new position with the current employer; and (5) becoming unemployed or inactive. The estimation methodology is a set of random effects probit models ${ }^{x v i i}$. Specifically, the four separate models estimate the probability of individuals moving to each of the four possible labour market outcomes (2),(3), (4), and (5) relative to a comparison group of those who remain in the same job (1).

Table 5 the results of main interest from the estimation of primary job mobility models with moonlighting and secondary job choices as the main explanatory variables in separate models. In Panel A of Table 5, it is found that individuals who have a second job are more likely to become self-employed in the next period than to remain in the same job (column 1). The magnitude of the effect of moonlighting is close to 100 percent, given the predicted probability of the model. There is also a positive relationship between moonlighting and getting a new job with a different employer, with the magnitude of the effect being in the order of 35 percent (column 2). In addition, multiple job holding is found to exert a negative impact on the probability of becoming unemployed or inactive (17 percent). The results of the full model of Panel A are presented in Appendix Table $\mathrm{A} 2^{\text {xviii }}$.

Panel B presents estimates in which moonlighting in a different job from the primary occupation is controlled for. We incorporate this variable capturing the difference in period $t$ in three distinct sets 
of specifications, i.e. difference at the 1-digit SOC (columns 5-8), at the 2-digit (columns 9-12) and the 3-digit (columns 13-16), respectively. The reference group comprises of individuals who moonlight in the same job as the primary occupation. A dummy variable for non-moonlighters is also incorporated in the specifications.

It is evident from Panel B that moonlighting in a different occupation in period $\mathrm{t}$ is positively associated with moving into a new job with a new employer in the period $t+1$. Moreover, it is negatively associated with moving into a new position with the same employer. The effects are of greater magnitude and significance when the main explanatory variable captures 2-digit and 3-digit SOC differences. For instance, individuals doing a different secondary occupation at the 2-digit level are some 15 percent more likely to move into a new job, and 27 percent less likely to move into a new position with the same employer (compared to individuals doing the same secondary occupation at the 2-digit SOC level), rather than stay in the same job. The results in Panel C suggest that serial moonlighters are 25 percent less likely to move into a new job with a new employer, rather than stay into the same job with the same employer.

The findings here suggest a positive association between second job-holding and secondary job choice and subsequent job mobility in the primary employment. A priori however, it is not clear what the direction of causality in this relationship should be. Individuals who want to change jobs and explore new career pathways may use secondary employment as means of obtaining the necessary skills in order to facilitate this transition. In that case, the decision to change careers results to second job-holding. It may also be the case though that people who hold a second job eventually are driven to a new primary job and a different career, despite the fact that initially they did not intend to. Therefore, second job-holding could also lead to future job mobility. The empirical framework enables us to identify this positive association between dual job-holding, secondary job occupation choice and future job mobility, but not to directly explore the direction of causality ${ }^{\text {xix }}$.

\section{[Insert Table 5 about here]}

\subsection{Multiple Job-Holding and Occupational Choice in the New Job}

As the estimates in Table 5 highlight the importance of dual job-holding for job mobility, the issue is now further explored by examining the occupational choices individuals make when changing jobs (either by becoming self-employed, getting a new job, or obtaining a new position with their current employer). The dependent variable captures different primary occupation in period $t+1$ compared to 
period $\mathrm{t}$ (in sets of three specifications, i.e. showing difference at the 1-digit SOC level, the 2-digit and the 3-digit respectively). As before, attention is paid on the effect of the main explanatory variable, i.e. holding two jobs in period $\mathrm{t}$ (in Panel A), the occupational choice in the second job in period t (in Panel B), measured as different secondary occupation), and serial moonlighting (in Panel C).

The occupational choice model in equation (13) is estimated separately for those who (a) become self-employed, (b) get a new job with a new employer or (c) a new position with the same employer at period $t+1$, with the job mobility models of columns I-IV in Table 5 serving as first stage regressions that correct for the potential incidental truncation bias ${ }^{\mathrm{xx}}$. The control group comprises of individuals staying in the same job. Linear probability models are thus estimated in the second stage, incorporating the inverse Mills ratios obtained in the first stage. The dependent variable takes the value 1 if individuals work in a different occupation in (a) self-employment (section I); (b) new job with a new employer (section II); and (c) new position with the same employer (section III). The estimates for the variables of main interest are presented in Table 6. In Panel A it is shown that moonlighting does not exert a significant impact on occupational diversification in the next year (either in self-employment or a new job or a new position). The full estimates for columns 1, 4 and 7 are illustrated in Panel B of the Appendix Table A2.

Panel B presents estimates of occupational choice in period $t+1$ controlling for the moonlighting occupational choices of the previous period. What becomes evident is that the occupational choices that individuals make as multiple job-holders can play an important role in terms of affecting their selected occupations in their new primary employment. In particular, individuals who carry out a different occupation in the primary and secondary job at period $t$ are more likely to perform a different occupation in the new primary job at period $t+1$, either in self-employment or in a new job with a new employer. In all specifications, the group that is the least likely to make a transition into a different occupational category comprises of moonlighters doing the same occupation as in their primary job. Non dual job-holders are more likely to transition into a new occupational category in the next year, compared to moonlighters in the same occupations as in their primary job.

\section{[Insert Table 6 about here]}

The associations between occupational choice in the second job and that of the new job are significant at all SOC digit levels for individuals switching into a different job in self-employment or 
a new job. They are marginally significant at the 2-digit SOC for individuals switching into a new position with the same employer. Specifically, moonlighters in a different 1-digit SOC code are more than twice as likely to transition to a different 1 -digit SOC code in self-employment in the next year and some 36 percent more likely to transition to a different 1-digit SOC code in a new paid job. Moonlighters in a different 2-digit SOC code are 45 percent more likely to transition to a different 2-digit SOC code in self-employment in the next year and some 37 percent more likely to transition to a different 2-digit SOC code in a new paid job. Moonlighters in a different 3-digit SOC code are 44 percent more likely to transition to a different 3-digit SOC code in self-employment in the next year and some 36 percent more likely to transition to a different 3-digit SOC code in a new paid job. Hence, the positive associations are robust to the inspection of differences in all three levels of the SOC codes, both at the moonlighting occupational choice and the new job/new position occupational choice.

\subsection{Alternative interpretations}

The findings of the last sections suggest that there are human capital spill-over effects between primary and secondary employment. Individuals may use multiple job-holding as a conduit for obtaining new skills and expertise and as a stepping stone to a new career. ${ }^{x \times i}$ Individuals doing a different occupation in their secondary job are more likely to change jobs and perform a different occupation in the next year.

However, there could be an alternative interpretation of the previous results. In regions with limited demand for a certain occupation, an individual could be performing a different occupation in his/her secondary job for primarily financial reasons, and then for the same reasons also be more likely to move to a different occupation in his primary job in the next year ${ }^{x i i}$. Moreover, financially vulnerable individuals could be moonlighting in self-employment jobs in order to escape poverty, and then move to subsistence self-employment jobs in the next year out of necessity. Such primarily financial motives would need to be ruled out as the primary candidate explanation of the results. All our previous specifications incorporate controls for regional unemployment, equivalized household income, occupation, industry and region of residence. Hence, to a great extend such concerns are mitigated. However, in this section we examine the determinants of variables approximating upward mobility in the next job. 
In Table 7 we present estimates of job outcomes in the year following the survey, using again the methodology described in Section 5.2. The occupational choice model in equation (13) is estimated separately for those who (a) become self-employed, (b) get a new job with a new employer or (c) a new position with the same employer at period $t+1$, with the job mobility models of columns I-IV in Table 5 serving as first stage regressions that correct for the potential incidental truncation bias. The control group comprises of individuals staying in the same job. Linear regression models are estimated in the second stage, incorporating the inverse Mills ratios obtained in the first stage. Three specific new job outcomes are examined, namely (a) the percentage monthly wage difference between the year $t+1$ and the year $t$; (b) upward wage mobility, defined as a binary variable taking the value 1 for a percentage monthly wage increase greater than 15\% compared to the last year; (c) upward skill group mobility between the year $t+1$ and the year $t$. This is a binary variable that takes the value 1 for a transition to a skilled non-manual occupational group in year $t+1$, by individuals working in skilled occupational categories in the year t (either manual or non-manual). Moreover, it also takes the value 1 if an individual transitions from any of the unskilled categories in year t to skilled occupations in the year $\mathrm{t}+1$. The four occupational skill categories are defined at the 1 -digit level $^{\text {xiiii }}$.

In Panel A of Table 7, it is shown that moonlighting exerts a significant impact on the probability of upward wage mobility for individuals switching into a new job in the year $t+1$. Specifically, moonlighters who switch into a new job in the next year earn 4 percentage points more than nonmoonlighters. Taking into account that the average predicted percentage wage change is 9.4 percent, this is an effect of a large magnitude. Moreover, moonlighters are 6.5 percentage points more likely to experience a monthly wage increase greater than 15 percent of their wage in year $t$. This amounts to an effect in the magnitude of 17 percent. The results are robust when hourly wages are used instead of monthly wages (available upon request).

The results presented in Panel B of Table 7 show that individuals moonlighting in different occupations in year $\mathrm{t}$ are more likely to transition to a new job at skilled occupational category in the year $\mathrm{t}+1$ compared to individuals moonlighting in the same occupation as in their primary job. Occupational diversification in moonlighting at the 1-digit SOC level exerts a 12.4 percentage point effect (around 85 percent given the linear prediction of the model) at the probability of transitioning to a skilled occupation for individuals moving into a new job in the year $\mathrm{t}+1$ (column B6). The effect is also significant for individuals moving into self-employment (column B3). The effects are 
somewhat smaller in magnitude for diversification at the 2-digit and the 3-digit SOC level, although significant and of a large magnitude (columns B15 and B24).

\section{[Insert Table 7 about here]}

Hence, moonlighting is associated with a wage increase for individuals moving into a new job, and moonlighting into different occupations is positively related to the probability of moving into a skilled occupational category in the next year. These results are considered to be in accordance with the human capital spillover interpretation of the previous results.

\section{Conclusion}

This study has investigated the inter-related dynamics of multiple job-holding, human capital and occupational choices between primary and secondary jobs, using a panel sample of UK employees from the British Household Panel Survey (BHPS) for the years 1991-2005. The sequential profile of the working lives of employees has been examined, investigating the motives of multiple jobholding, its impact on the probability of job mobility and the associated spillover effects on occupational transition between alternative main jobs.

The analysis reveals that multiple job-holding, in addition to being a temporary response to hours-constraints, increased labour market uncertainty, and financial shocks, contains a permanent labour market element as it appears to be persistent over time. The examination of the occupational choice in the second job also provides some interesting insights. Individuals facing increased commitments or financial constraints are found to be more likely to do the same occupation in both their primary and secondary job, exploiting the higher earnings opportunities that their accumulated occupational experience may entail. This result is further strengthened by the fact that individuals with lengthier occupational experience in their primary job are less likely to choose a different occupation in their second job. Nevertheless, individuals who enjoy a relative sense of financial security are found to be more likely to explore different occupational paths in their secondary employment to satisfy their intrinsic preferences.

Multiple job-holding is estimated to be an important determinant of job mobility decisions. Moonlighting is found to increase the probability of becoming self-employed or getting a new job, while it decreases the probability of becoming unemployed or inactive, compared to staying at the 
same job. Moreover, individuals doing different occupations in their secondary employment are more likely to change jobs in the following year. The estimates also suggest that there are human capital spill-over effects between primary and secondary employment. The occupational choices that individuals make as multiple job-holders play an important role in the occupational paths that they follow afterwards. In particular, individuals who carry out the same occupation in the primary and secondary job at period $t$ are less likely to perform a different occupation in the new primary job at period $t+1$. The opposite is true for those who do different occupations in their primary and secondary jobs at the previous period $t$. The evidence provided in this study suggests that individuals may be using multiple job-holding as a conduit for obtaining new skills and expertise and as a stepping stone to new careers, particularly ones that involve self-employment. This empirical finding is in support of the proposition derived in theoretical discussion of Section 3. We acknowledge however the possibility that second job-holding may be endogenous in the occupational mobility decision, and that the literature can benefit from complementary empirical evidence on the direction of causality stemming from alternative identification strategies.

From a policy point of view, the findings suggest that, depending on the motives behind moonlighting, different approaches with distinct priorities and objectives may be pursued. The evidence indicates that for more vulnerable groups of people, particularly those on low incomes and with low education, moonlighting may be more of a necessity rather than a choice. Whereas, more financially stable individuals can "afford" to use multiple job-holding as an avenue to develop and enrich their skills, explore alternative career paths and pursue possible entrepreneurial activities through self-employment. The policy priorities in the first case should probably focus more on strengthening job security and on safeguarding a stable income stream to the vulnerable segments of society. Furthermore, issues related to work-life balance and overall well-being may warrant particular attention, since individuals who face financial hardships may be induced to compromise their physical and mental health when working in multiple jobs. For the second group of people, moonlighting may be a useful avenue through which labour market flexibility, innovation and entrepreneurship can be fostered. There is an increasing policy interest for nurturing the employability of individuals within a highly mobile and flexible labour market (Employment in Europe, 2004). Based on the results of this study, moonlighting is found to be a potential mechanism that can facilitate this process. Policy priorities could therefore focus on identifying ways 
through which multiple job-holding can lead to the more efficient acquisition of skills, and to promote future potential entrepreneurial initiatives.

\section{References}

Acemoglu, D. and Autor, D. (2011) Skills, tasks and technologies: Implications for employment and earnings. In The Handbook of Labor Economics (eds. Ashenfelter O. and D. Card), Elsevier, Vol. 4, Part B, xciiixcvi.

Alden, J. (1971) Double jobholding: A regional analysis of Scotland. Scottish Journal of Political Economy, 18, 99 112.

Alden, J. and Spooner, R. (1982) Multiple job holders: An analysis of second-jobs in the European Community. Luxemburg: Office for Official Publications of the European Communities.

Amuédo-Dorantes, C. and Kimmel, J. (2009) Moonlighting behavior over the business cycle. Economic Inquiry, 47(4), 754-765.

Averett, S. L. (2001) Moonlighting: Multiple motives and gender gifferences. Applied Economics, 33, 1391-1410.

Bell, D., Hart, R. A. and Wright, R. E. (1997) Multiple job holding as a 'hedge' against unemployment. CEPR Discussion Paper No. 1626.

Berger, M. C. (1988) Predicted future earnings and choice of college major. Industrial and Labor Relations Review, 41(3), 418-429.

Blundell, R. and MaCurdy T.E. (1999) Labor Supply: A Review of Alternative Approaches. In The Handbook of Labor Economics (eds. Ashenfelter O. and D. Card). Vol. 3, 1559-1696.

Böheim, R. and Taylor, M.P. (2004) And in the evening she's a singer with the band - Second jobs, plight or pleasure? IZA Discussion Paper No. 1081. Bonn, Germany: Institute for the Study of Labor.

Boskin, M. J. (1974) A conditional logit model of occupational choice. The Journal of Political Economy, 82(2), 389-398.

Chamberlain, G. (1984) Panel data. In The Handbook of Econometrics (eds. Z. Griliches and M. Intriligator). Vol. 2, Chapter 22, North Holland.

Conway, K. S., and Kimmel, J. (1998) Male labor supply estimates and the decision to moonlight. Labour Economics. 5, 135-166.

Demirgüc-Kunt, A., Klapper, L. F. and Panos G. A. (2011) Entrepreneurship in post-conflict transition: The role of informality and access to finance. Economics of Transition, 19(1), 27-78.

Demirgüç-Kunt A., Klapper L. F., and Panos G. A. (2013). Entrepreneurial finance in the Western Balkans: Characteristics of the newly self-employed in Albania, Bosnia \& Herzegovina, and Serbia. In Banking the World: Empirical Foundations of Financial Inclusion (eds. Kull R., Demirgüç-Kunt A., and Morduch, R. Boston, MA: MIT Press: Forthcoming.

Denvil, D. and Sabirianova Peter, K. (2010) Does labor supply respond to a flat tax? Evidence from the Russian tax reform. Economics of Transition, 18(2), 365-404.

Dickens, R. (2000) Caught in a trap? Wage mobility in Great Britain: 1975-1994. Economica, 67, 477-497.

Dickey, H. and Theodossiou, I. (2006) Who has two jobs and why? Evidence from rural coastal communities in west scotland. Agricultural Economics, 34(10), 291-301.

Dustmann, C. and Rochina-Barrachina, M. E. (2007) Selection correction in panel data models: An application to the estimation of females' wage equations. Econometrics Joumal, 10(2), 263-293.

European Commission (2002). Employment in Europe 2002. Recent trends and prospects. Report by the Directorate-General for Employment and Social Affairs. 
European Commission (2004). Employment in Europe 2004. Recent trends and prospects (Labour market transitions and advancement: temporary employment and low-pay in Europe). Report by the Directorate-General for Employment and Social Affairs.

European Commission (2009). Employment in Europe Report 2009. Report by the Directorate-General for Employment, Social Affairs and Equal Opportunities.

European Union Information Website: EurActiv. (2010) Flexicurity: Europe's employment solution? Available at: http://www.euractiv.com/en/print/socialeurope/flexicurity-europe-employmentsolution/article-169840.

Evers M., De Mooij R., and Van Vuuren D. (2008) The Wage Elasticity of Labour Supply: A Synthesis of Empirical Estimates. De Economist, 156, 25-43.

Farber, H. S. (1998) Are lifetime jobs disappearing? Job duration in the United States: 1973-1993. In Labor Statistics Measurement Issues (eds. J. Haltiwanger, M. Manser, and R. Topel). Chicago, IL:: University of Chicago Press.

Freeman, R. B. (1971) The market for college-trained manpower: A study in the economics of career choice. Cambridge, MA: Harvard University Press.

Gathmann, G., and Schönberg, U. (2010) How general is human capital? A task-based approach. Journal of Labor Economics, 28(1), 1-49.

Geel, R., and U. Backes-Gellner (2009). Occupational mobility within and between skill clusters: An empirical analysis based on the skill-weights approach. Economics of Education Working Paper Series 0047, University of Zurich, Institute for Strategy and Business Economics (ISU).

Gregg, P. and Wadsworth, J. (1995) A short history of labour turnover, job tenure, and job security, 1975-93. Oxford Review of Economic Policy, 11, 73-90.

Gregg, P. and Wadsworth, J. (1996) Mind the gap, please? The changing nature of entry jobs in Britain. LSE Discussion Paper 303, Centre of Economic Performance.

Gregg, P. and Wadsworth, J. (1999) Job tenure, 1975-98. In The State of Working Britain (eds. P. Gregg and J. Wadsworth), Manchester University Press.

Guariglia, A. and Kim, B.-Y. (2004) Earnings uncertainty, precautionary saving and moonlighting in Russia. Journal of Population Economics, 17, 289-310.

Guariglia, A. and Kim, B.-Y. (2006) The dynamics of moonlighting in Russia: What is happening in the Russian informal economy. Economics of Transition, 14(1), 1-45.

Guthrie, H. W. (1969) Teachers in the moonlight. Monthly Labour Review, 92, 28-31

Hamel, H.R. (1967). Moonlighting - An economic phenomenon. Monthly Labour Review, 90, 17-22.

Harrison, B. (1998). The dark side of flexibility. Challenge, 41,117-127.

Heckman, J. J. (1979). Sample selection bias as a specification error. Econometrica, 47(1), 153-161.

Heckman, J. J. (1981) The incidental parameters problem and the problem of initial conditions in estimating a discrete time - discrete data stochastic process. In Structural Analysis of Discrete Data with Econometric Applications (eds. C.F. Manski and D. McFadden), Cambridge, MA: MIT Press, 179-195.

Heineck, G. and Schwarze, J. (2004) Fly me to the moon: The determinants of secondary jobholding in Germany and the U.K. IZA Discussion Paper No. 1358. Bonn, Germany: Institute for the Study of Labor.

Hersch, J., and Stratton L.S. (1997). Housework, fixed effects, and wages of married workers. Journal of Human Resources, 32, 285-307.

Hunt, J. C., Hill, C. R. and Kiker, B. F. (1985) The effect of taxation on labour supply: the case of moonlighting. Applied Economics, 17(5), 897-905.

Jäckle, R. (2007) Health and wages: Panel data estimates considering selection and endogeneity. Working Paper No. 43, Ifo Institute for Economic Research at the University of Munich. 
Jones, A. M. and Labeaga, J. M. (2003) Individual heterogeneity and censoring in panel data estimates of tobacco expenditure. Journal of Applied Econometrics, 18(2), 157-177.

Kambourov, G. and Manovskii, I. (2009a) Occupational mobility and wage inequality. Review of Economic Studies, 76(2), 731-759.

Kambourov, G. and Manovskii, I. (2009b) Occupational specificity of human capital. International Economic Review, 50(1), 63-115.

Keith, K., and A. McWilliams (1995). The wage effects of cumulative job mobility. Industrial and Labor Relations, 49, 121-137.

Keith, K., and McWilliams A. (1999). The returns to mobility and job search by gender. Industrial and Labor Relations, 52, 460-477.

Kimmel, J. and Powell, L. M. (1999) Moonlighting trends and related policy issues in Canada and the United States. Canadian Public Policy, 25, 207-231.

Kimmel, J. and Conway, K. S. (2001) Who moonlights and why? Evidence from the SIPP. Industrial Relations, 40, 89-120.

Krishnan, P. (1990) The economics of moonlighting: A double self-selection model. Review of Economics and Statistics, 72, 361-7.

Kyriazidou, E. (1997) Estimation of a panel data sample selection model. Econometrica, 65(6), 1335-1364.

Lazear, E.P. (2009) Firm-specific human capital: A skill-weights approach. Journal of Political Economy, 117(5), 914-940.

Lemieux, T., Fortin, B. and Frechette, P. (1994) The effect of taxes on labor supply in the underground economy. American Economic Review, 84(1), 231-254.

Levenson, A. R. and Maloney, W. F. (1998) The informal sector, firm dynamics and institutional participation. World Bank Policy Research Working Paper No. 1988. Washington, DC: The World Bank.

Lundberg, P. (1995) Job amenity and the incidence of double work. Journal of Economic Behavior and Organization, 26, 273 - 287.

Machin, S. (1999) Wage inequality in the 1970s, 1980s and 1990s. In The State of Working Britain (eds. P. Gregg and J. Wadsworth), Manchester University Press.

Montmarquette, C., Cannings, K. and Mahseredjian, S. (2002) How do young people choose college majors? Economics of Education Review, 21(6), 543-556.

Mundlak, Y. (1978) On the pooling of time-series and cross section data. Econometrica, 46(1), 69-85.

Neal, D. (1995) Industry-specific human capital: Evidence from displaced workers. Journal of Labor Economics, 13(4), 653-677.

Neumark, D. (2000) Changes in job stability and job security: A collective effort to untangle, reconcile and interpret the evidence. NBER Working Paper No. 7472, Cambridge, MA: National Bureau of Economic Research.

Organisation for Economic Co-operation and Development. (1997) Employment Outlook 1997.

Parent, D. (2000) Industry-specific capital and the wage profile: Evidence from the National Longitudinal Survey of Youth and the Panel Study of Income Dynamics. Journal of Labor Economics, 18, 306-321.

Parsons, D.O. (1991). The job search behaviour of employed youth. Review of Economics and Statistics, 73, 597604.

Partridge, M. (2002) Moonlighting in a high growth economy: Evidence from U.S. state-level data. Growth and Change, 33(4), 424-452.

Pavan, R. (2011) Career Choice and Wage Growth. Journal of Labor Economics, 29(3), 549-587.

Paxson, C. H. and Sicherman, N. (1996) The dynamics of dual job holding and job mobility. Journal of Labor Economics, 14(3), 357-393. 
Perlman, R. (1966) Observations on overtime and moonlighting. Southern Economic Journal, 33(2), 237-244.

Poletaev, M. and Robinson, C. (2008) Human capital specificity: Evidence from the dictionary of occupational titles and displaced worker surveys 1984-2000. Journal of Labor Economics, 26, 387-420.

Renna, F. and Oaxaca, R. L. (2006) The economics of dual job holding: A job portfolio model of labor supply. IZA Discussion Paper No. 1915. Bonn, Germany: Institute for the Study of Labor.

Renna, F. (2006) Moonlighting and overtime: A cross-country analysis. Journal of Labor Research, 27(4), 575591.

Robinson, H. and Wadsworth, J. (2007) Impact of the minimum wage on the incidence of second job holding in Britain. Scottish Journal of Political Economy, 54(4), 553-574.

Robinson, C. (2011) Occupational mobility, occupational distance and specific human capital. CIBC Working Paper \# 2011-5.

Rosen, S., (1983) Specialization and human capital. Journal of Labor Economics. 1(1), 43-49,

Semykina, A. and Wooldridge, J. M. (2005) Estimating panel data models in the presence of endogeneity and selection: Theory and applications. Michigan State University Working Paper.

Shaw, K. L. (1987) Occupational change, employer change, and the transferability of skills. Southern Economic Journal, 53(3), 702-719.

Shishko, R. and Rostker, B. (1976) The economics of multiple job holding. American Economic Review, 66, 298308.

Simic, M. and Sethi, S. (2002) People with second jobs: Analysis of the trends and characteristics of people who do two jobs. Labour Market Trends, 110(5), 239-247.

Stewart, M. B. (1999) Low pay in Britain. In The State of Working Britain (eds. P. Gregg and J. Wadsworth), Manchester University Press.

Stewart, M. B. (2007) The interrelated dynamics of unemployment and low-wage employment. Journal of Applied Econometrics, 22(3), 511 - 531.

Stewart, M. B. and Swaffield, J. (1999) Low pay dynamics and transition probabilities. Economica, 66, 23-42.

Theodossiou, I. (2002) Factors affecting the job to joblessness turnover and gender. Labour, 16, 729-746.

Trades Union Congress (2007). Time to tackle the training divide. Available at: http://www.tuc.org.uk/skills/tuc-13698-f0.cfm

Trades Union Congress (2012). Labour Market Report, No 24, March 2012. Available at: http://www.tuc.org.uk/economy/tuc-20797-f0.pdf

van Ophem, H. (1991). Wages, nonwage job characteristics, and the search behavior of employees, Review of Economics and Statistics, 73, 145-151.

Webb, S., Kemp, M. and Millar, J. (1996) The changing face of low pay in Britain. Policy Studies, 17, 255-271.

Williams, N. (2009) Seniority, experience, and wages in the UK. Labour Economics, 16(3), 272-283.

Wooldridge, J. M. (1995) Selection corrections for panel data models under conditional mean independence assumptions. Journal of Econometrics, 68(1), 115-132.

Wooldridge, J. M. (2005) Simple solutions to the initial conditions problem in dynamic, nonlinear panel data models with unobserved heterogeneity. Journal of Applied Econometrics, 20(1), 39-54.

Wu, Z., Baimbridge, M. and Zhu, Y. (2009) Multiple job holding in the United Kingdom: Evidence from the British household panel survey. Applied Economics, 41(21), 2751-2766

Zangelidis, A. (2008a) Occupational and industry specificity of human capital in the British labour market. Scottish Journal of Political Economy, 55(4), 420-443.

Zangelidis, A. (2008b) Seniority profiles in unionised workplaces: Do unions still have the edge?. Oxford Bulletin of Economics and Statistics, 70(3), 327-345. 
Figure 1: The Incidence of Male Dual Job-Holding and Unemployment Rates

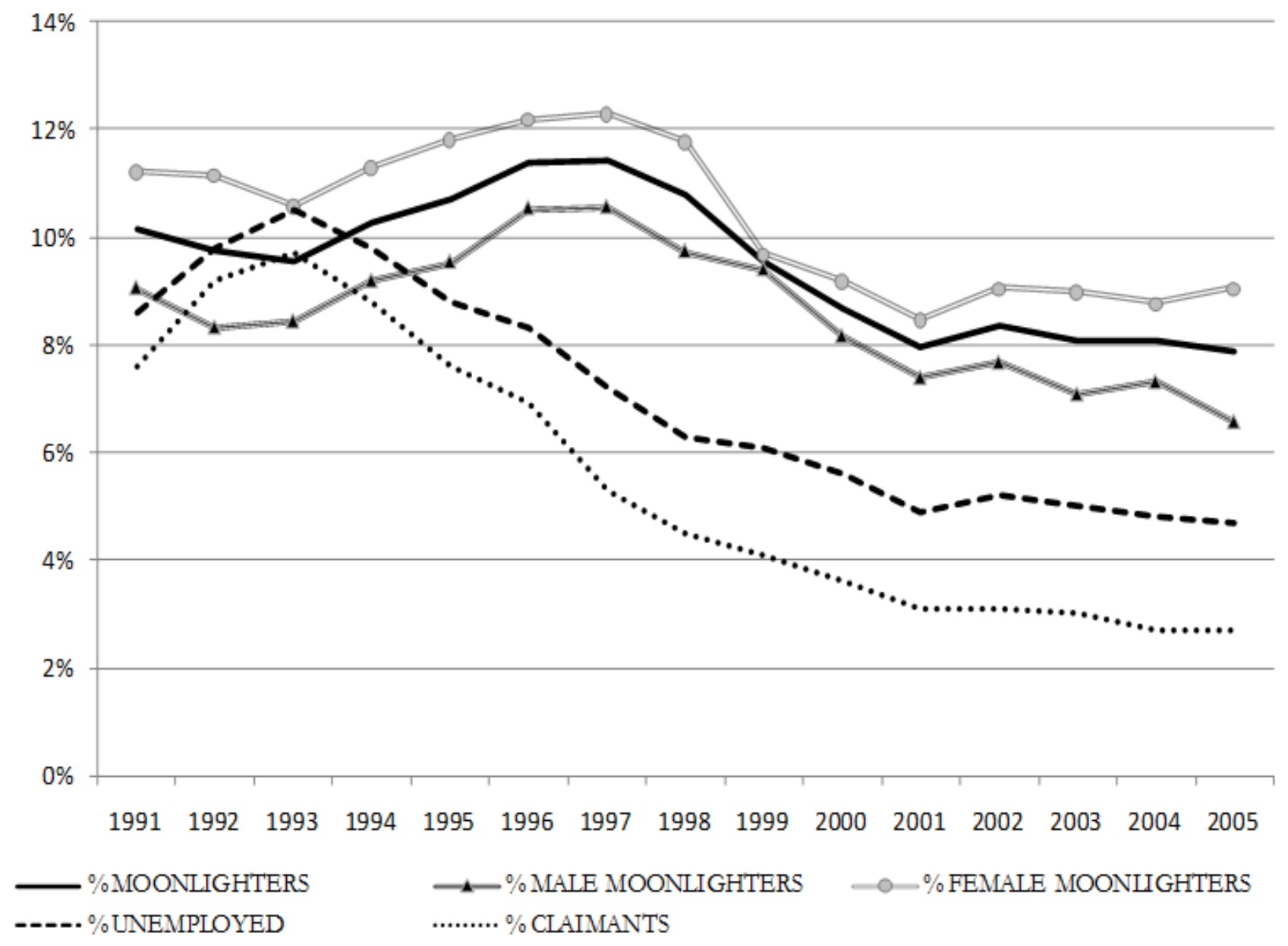

Notes: Moonlighting data are from the BHPS. Unemployment and Local Claimants' rate data are from National Statistics Online. 
Table 1: Summary Statistics for Primary and Secondary Jobs

\begin{tabular}{|c|c|c|c|c|c|c|}
\hline \multicolumn{7}{|c|}{ Panel A: Sample of paid employees in primary job } \\
\hline \multirow{2}{*}{\multicolumn{3}{|c|}{ \# Obs. [No. of individuals] }} & \multicolumn{2}{|c|}{ Primary Job } & \multicolumn{2}{|c|}{ Secondary Job } \\
\hline & & & 37,209 & \multirow{2}{*}{$\frac{[5,583]}{(0.26)}$} & 2,600 & {$[1,080]$} \\
\hline \multirow{2}{*}{\multicolumn{3}{|c|}{$\begin{array}{l}\text { Dual Job Holder } \\
\text { Weekly Hours }\end{array}$}} & $7.0 \%$ & & \multicolumn{2}{|l|}{-} \\
\hline & & & $39.47 \quad(7.42)$ & {$[39.00]$} & \multicolumn{2}{|c|}{$6.08 \quad(5.44)$} \\
\hline \multicolumn{3}{|l|}{ Monthly Hours } & \multicolumn{2}{|c|}{$\begin{array}{c}169.11(31.78) \\
{[167.12]}\end{array}$} & \multicolumn{2}{|c|}{$\begin{array}{c}26.04 \quad(23.32) \\
{[20.00]}\end{array}$} \\
\hline \multicolumn{3}{|l|}{ Real Monthly Earnings } & \multicolumn{2}{|c|}{$\begin{array}{c}1,340.41 \quad(878.21) \\
{[1,168.60]}\end{array}$} & $\begin{array}{r}230.81 \\
{[13}\end{array}$ & $\begin{array}{l}(368.40) \\
6.05]\end{array}$ \\
\hline \multicolumn{3}{|l|}{ Real Hourly Earnings } & \multicolumn{2}{|c|}{$[6.22]$} & \multicolumn{2}{|c|}{ [6.94] } \\
\hline \multicolumn{7}{|l|}{ Occupation (1-digit SOC) } \\
\hline Managers \& administrators & & & $17.9 \%$ & $(0.38)$ & $6.1 \%$ & $(0.24)$ \\
\hline Professional occupations & & & $10.4 \%$ & $(0.30)$ & $10.3 \%$ & $(0.30)$ \\
\hline Assoc. professional \& technical occ. & & & $10.6 \%$ & $(0.31)$ & $20.7 \%$ & $(0.40)$ \\
\hline Clerical \& secretarial occupations & & & $9.7 \%$ & $(0.30)$ & $3.7 \%$ & $(0.19)$ \\
\hline Craft \& related occupations & & & $18.7 \%$ & $(0.39)$ & $17.8 \%$ & $(0.38)$ \\
\hline Personal \& protective service occ. & & & $6.5 \%$ & $(0.25)$ & $20.4 \%$ & $(0.40)$ \\
\hline Sales occupations & & & $4.6 \%$ & $(0.21)$ & $3.2 \%$ & $(0.18)$ \\
\hline Plant \& machine operatives & & & $14.8 \%$ & $(0.35)$ & $5.6 \%$ & $(0.23)$ \\
\hline \multicolumn{7}{|l|}{ Other $2^{\text {nd }}$ job characteristics } \\
\hline \multicolumn{3}{|c|}{ Different SOC between $2^{\text {nd }}$ and primary job (1-digit) } & \multicolumn{2}{|l|}{-} & $68.0 \%$ & $(0.47)$ \\
\hline Different SOC between $2^{\text {nd }}$ and primary & job (2-digi & & - & & $79.0 \%$ & $(0.41)$ \\
\hline Different SOC between $2^{\text {nd }}$ and primary & job (3-digi & & - & & $84.0 \%$ & $(0.37)$ \\
\hline Serial Moonlighter & 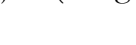 & & - & & $49.1 \%$ & $(0.50)$ \\
\hline Temporary Moonlighter & & & - & & $50.9 \%$ & $(0.50)$ \\
\hline Serial Moonlighter & & & - & & $49.5 \%$ & $(0.50)$ \\
\hline Paid Employee & & & - & & $50.5 \%$ & $(0.50)$ \\
\hline Panel B: Sample of dual job holders & & & & & & \\
\hline & $\underline{1-\mathrm{d}}$ & SOC & $\underline{2-d i}$ & it SOC & 1-dig & $\mathrm{t} \mathrm{SOC}$ \\
\hline$\frac{\text { Occupational choice in the second job }}{\# \text { Obs. [No. of individuals] }}$ & $\begin{array}{c}\text { Different } \\
1,764\end{array}$ & $\begin{array}{c}\text { Same } \\
832\end{array}$ & $\begin{array}{c}\text { Different } \\
2,043\end{array}$ & $\begin{array}{c}\text { Same } \\
543\end{array}$ & $\begin{array}{c}\text { Different } \\
2,173\end{array}$ & $\begin{array}{c}\text { Same } \\
413\end{array}$ \\
\hline Primary job characteristics: & & & & & & \\
\hline Weekly Hours & 38.26 & 38.64 & 38.41 & 38.31 & 38.29 & 38.93 \\
\hline Monthly Hours & 163.94 & 165.59 & 164.57 & 164.16 & 164.05 & 166.82 \\
\hline Real Monthly Earnings & $1,149.31$ & $1,301.14^{* * *}$ & $1,171.23$ & $1,291.92 * * *$ & $1,176.08$ & $1,304.10^{* * *}$ \\
\hline Real Hourly Earnings & 6.69 & $7.52^{* * *}$ & 6.76 & $7.62^{* * *}$ & 6.85 & $7.43^{* * *}$ \\
\hline Secondary job characteristics: & & & & & & \\
\hline Weekly Hours & $6.39 * * *$ & 5.43 & $6.34 * * *$ & 5.08 & $6.25^{* * *}$ & 5.13 \\
\hline Monthly Hours & $27.38^{* * *}$ & 23.25 & $27.16^{* * *}$ & 21.77 & $26.80^{* * *}$ & 22.00 \\
\hline Real Monthly Earnings & 214.82 & $265.77 * * *$ & 221.88 & $266.12^{* * *}$ & 222.35 & $277.54 * * *$ \\
\hline Real Hourly Earnings & 13.09 & $17.64 * * *$ & 13.74 & $17.39 * * *$ & 13.78 & $18.32^{* * *}$ \\
\hline Serial Moonlighter & $49.15 \%$ & $49.28 \%$ & $49.29 \%$ & $49.36 \%$ & $49.42 \%$ & $48.67 \%$ \\
\hline Self-Employed & $45.69 \%$ & $57.69 \%$ \%*** & $47.09 \%$ & $59.48 \%$ \%*** & $47.31 \%$ & $62.23 \% * * *$ \\
\hline
\end{tabular}

Notes: The table presents means and standard deviations in parentheses. Medians are presented in brackets for selected variables. 
Table 2: Summary Statistics and Mean Differences

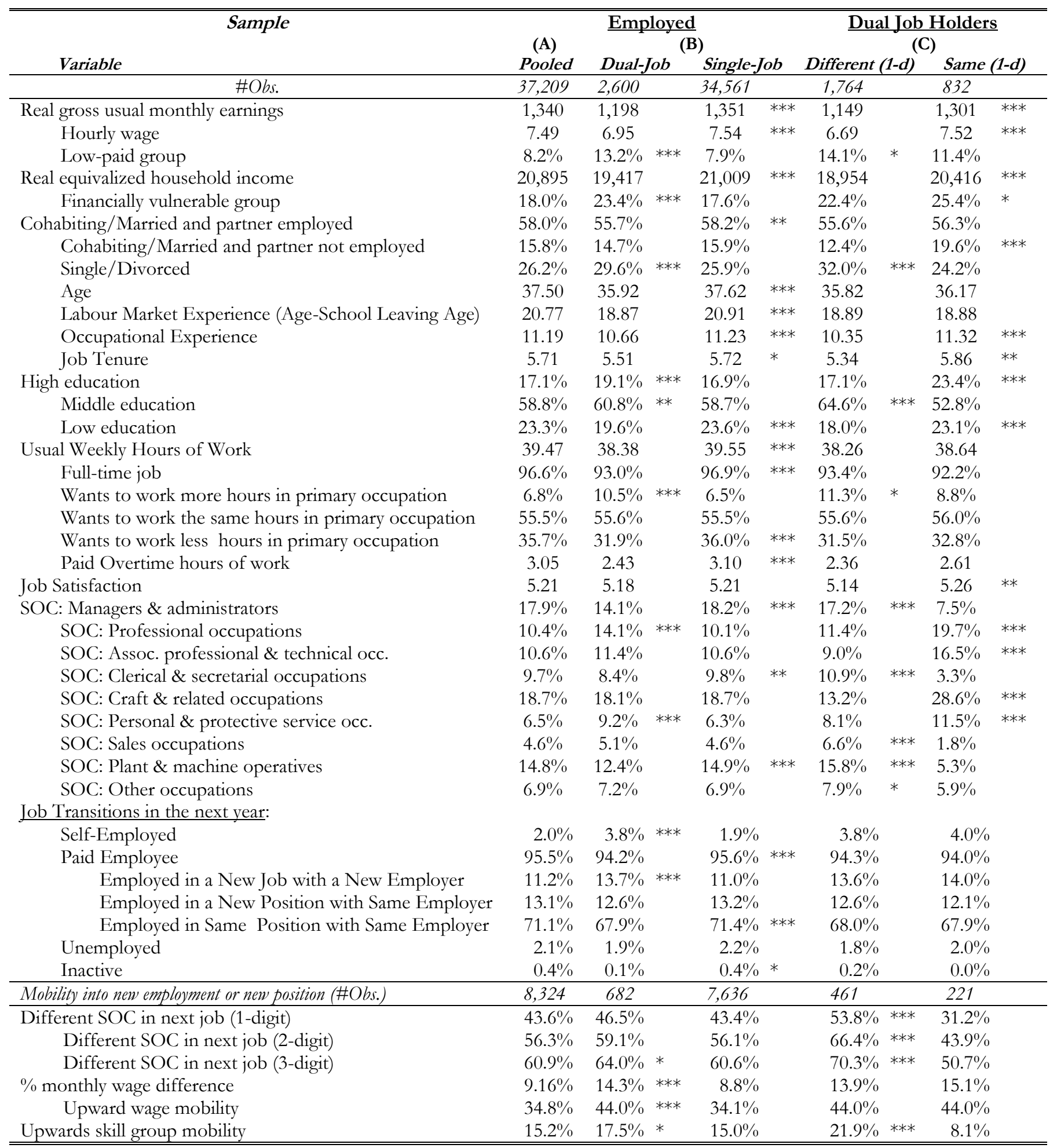

Notes: ${ }^{*} \mathrm{p}<0.10,{ }^{* *} \mathrm{p}<0.05,{ }^{* * *} \mathrm{p}<0.01$ from a t-test between mean differences. 
Table 3: The Profile of the Dual Job-Holder

Wooldridge Estimator: Dynamic Random Effects Probit with Mundlak terms

\begin{tabular}{|c|c|c|c|c|c|c|}
\hline \multirow{2}{*}{ Dependent Variable: Dual-Job Holder } & \multicolumn{2}{|c|}{ Level effects } & \multicolumn{2}{|c|}{ Average effects } & \multicolumn{2}{|c|}{ Permanent effects } \\
\hline & M.Eff. & [S.E.] & M.Eff. & [S.E.] & M.Eff. & [S.E.] \\
\hline Moonlighting $_{(\mathrm{t}-1)}$ & $0.106^{* * *}$ & {$[0.015]$} & - & & - & \\
\hline Moonlighting $_{(\text {Year1) }}$ & $0.078^{* * *}$ & {$[0.010]$} & - & & - & \\
\hline $\log ($ Equivalized household income in the last year) & $-0.007 * * *$ & {$[0.002]$} & $0.007 * * *$ & {$[0.003]$} & -0.001 & {$[0.002]$} \\
\hline Local unemployment rate & $0.001 *$ & {$[0.001]$} & $-0.001 *$ & {$[0.001]$} & 0.001 & {$[0.001]$} \\
\hline Job satisfaction & $-0.001 * *$ & {$[0.000]$} & $0.001 *$ & {$[0.001]$} & 0.001 & {$[0.001]$} \\
\hline Log(Experience $)$ & -0.002 & {$[0.003]$} & 0.001 & {$[0.003]$} & -0.001 & {$[0.001]$} \\
\hline $\log ($ Occupational experience $)$ & 0.001 & {$[0.001]$} & $-0.003^{* *}$ & {$[0.002]$} & $-0.003 * *$ & {$[0.001]$} \\
\hline $\log ($ Tenure $)$ & $0.002^{* * *}$ & {$[0.001]$} & $-0.003 * * *$ & {$[0.001]$} & -0.001 & {$[0.001]$} \\
\hline Wants to work more hours in primary job & 0.003 & {$[0.002]$} & $0.011 * *$ & {$[0.004]$} & $0.013^{* * *}$ & {$[0.004]$} \\
\hline Wants to work the same hours in primary occupation & $\{\operatorname{Ref}\}$. & & $\{\operatorname{Ref}\}$. & & $\{$ Ref. $\}$ & \\
\hline Wants to work less hours in primary job & $-0.002^{* *}$ & {$[0.001]$} & 0.002 & {$[0.002]$} & -0.001 & {$[0.002]$} \\
\hline $\log ($ Weekly hours in primary job) & 0.001 & {$[0.003]$} & -0.004 & {$[0.004]$} & -0.004 & {$[0.004]$} \\
\hline Log(Paid overtime hours) & $-0.001 * * *$ & {$[0.000]$} & $0.001 * *$ & {$[0.001]$} & -0.001 & {$[0.000]$} \\
\hline Cohabiting/Married and spouse employed & -0.001 & {$[0.002]$} & -0.002 & {$[0.003]$} & -0.003 & {$[0.002]$} \\
\hline Cohabiting/Married and spouse not employed & -0.002 & {$[0.002]$} & $-0.006^{*}$ & {$[0.004]$} & $-0.009 * * *$ & {$[0.003]$} \\
\hline Single/Divorced & $\{\operatorname{Ref}\}$. & & $\{\operatorname{Ref}\}$. & & $\{R e f\}$. & \\
\hline Log(No. of children $)$ & -0.001 & {$[0.001]$} & $0.003^{* * *}$ & {$[0.001]$} & $0.002^{* * *}$ & {$[0.001]$} \\
\hline Private sector & $-0.006^{*}$ & {$[0.003]$} & 0.003 & {$[0.004]$} & -0.002 & {$[0.003]$} \\
\hline Permanent job & 0.001 & {$[0.002]$} & $-0.012^{* *}$ & {$[0.005]$} & $-0.012 * * *$ & {$[0.004]$} \\
\hline Promotion prospects in primary job & -0.001 & {$[0.001]$} & $-0.005^{* *}$ & {$[0.002]$} & $-0.006 * * *$ & {$[0.002]$} \\
\hline Annual increments & $-0.002^{*}$ & {$[0.001]$} & -0.002 & {$[0.002]$} & $-0.004 * *$ & {$[0.002]$} \\
\hline High education & $\{\operatorname{Ref}\}$. & & $\{R e f\}$. & & $\{\operatorname{Ref}\}$. & \\
\hline Middle education & 0.004 & {$[0.005]$} & -0.003 & {$[0.006]$} & 0.001 & {$[0.002]$} \\
\hline Low education & -0.005 & {$[0.006]$} & 0.006 & {$[0.009]$} & 0.001 & {$[0.003]$} \\
\hline \multicolumn{7}{|l|}{ Occupation (1-digit SOC codes): } \\
\hline Managers and administrators & $\{\operatorname{Ref} \cdot\}$ & & $\{R e f \cdot\}$ & & $\{R e f\}$. & \\
\hline Professional occupations & 0.002 & {$[0.003]$} & 0.006 & {$[0.004]$} & $0.007 * *$ & {$[0.003]$} \\
\hline Associate professional \& technical occupations & 0.002 & {$[0.003]$} & 0.006 & {$[0.004]$} & $0.008^{* * *}$ & {$[0.003]$} \\
\hline Clerical \& secretarial occupations & 0.002 & {$[0.003]$} & -0.002 & {$[0.004]$} & 0.001 & {$[0.004]$} \\
\hline Craft \& related occupations & 0.002 & {$[0.003]$} & 0.003 & {$[0.004]$} & $0.006^{*}$ & {$[0.003]$} \\
\hline Personal \& protective service occupations & $0.014^{*}$ & {$[0.007]$} & -0.002 & {$[0.005]$} & $0.007^{*}$ & {$[0.004]$} \\
\hline Sales occupations & 0.006 & {$[0.005]$} & 0.002 & {$[0.005]$} & $0.007^{*}$ & {$[0.004]$} \\
\hline Plant \& machine operatives & 0.004 & {$[0.003]$} & 0.002 & {$[0.004]$} & $0.006^{*}$ & {$[0.003]$} \\
\hline Other occupations & 0.005 & {$[0.004]$} & -0.004 & {$[0.005]$} & 0.001 & {$[0.004]$} \\
\hline \multicolumn{7}{|l|}{ Industry (SIC codes): } \\
\hline Agriculture, hunting and forestry or fishing & 0.001 & {$[0.005]$} & 0.008 & {$[0.007]$} & 0.008 & {$[0.005]$} \\
\hline Mining and quarrying & 0.002 & {$[0.009]$} & -0.009 & {$[0.011]$} & -0.007 & {$[0.009]$} \\
\hline Manufacturing & 0.002 & {$[0.003]$} & $-0.010 * *$ & {$[0.004]$} & $-0.008^{* *}$ & {$[0.003]$} \\
\hline Electricity, gas and water supply & $-0.005^{*}$ & {$[0.003]$} & -0.015 & {$[0.011]$} & $-0.023 * *$ & {$[0.010]$} \\
\hline Construction & $\{\operatorname{Ref} \cdot\}$ & & $\{\operatorname{Ref}\}$. & & $\{R e f \cdot\}$ & \\
\hline Wholesale and retail trade & 0.004 & {$[0.004]$} & -0.003 & {$[0.005]$} & 0.001 & {$[0.003]$} \\
\hline Hotels and restaurants & 0.003 & {$[0.006]$} & -0.005 & {$[0.007]$} & -0.002 & {$[0.005]$} \\
\hline Transport, storage and communication & -0.004 & {$[0.003]$} & 0.002 & {$[0.006]$} & -0.003 & {$[0.004]$} \\
\hline Financial intermediation & 0.007 & {$[0.008]$} & -0.006 & {$[0.006]$} & 0.001 & {$[0.004]$} \\
\hline Real estate, renting and business & 0.001 & {$[0.003]$} & -0.001 & {$[0.005]$} & -0.001 & {$[0.004]$} \\
\hline Public administration and defence & -0.002 & {$[0.003]$} & 0.005 & {$[0.006]$} & 0.003 & {$[0.004]$} \\
\hline Education & $-0.004 *$ & {$[0.003]$} & $0.015^{* *}$ & {$[0.007]$} & $0.009 *$ & {$[0.005]$} \\
\hline Health and social work & 0.001 & {$[0.005]$} & 0.005 & {$[0.007]$} & 0.006 & {$[0.005]$} \\
\hline Other community, social \& personal service activities & 0.001 & {$[0.005]$} & 0.002 & {$[0.007]$} & 0.003 & {$[0.005]$} \\
\hline Private households with employees & 0.052 & {$[0.128]$} & 0.050 & {$[0.051]$} & $0.069 *$ & {$[0.041]$} \\
\hline
\end{tabular}

Table 3 continued in next page 
Table 3 continued from last page

\begin{tabular}{|c|c|c|c|c|c|c|}
\hline & \multicolumn{2}{|c|}{ Level effects } & \multicolumn{2}{|c|}{ Average effects } & \multicolumn{2}{|c|}{ Permanent effects } \\
\hline & M.Eff. & [S.E.] & M.Eff. & [S.E.] & M.Eff. & [S.E.] \\
\hline Extra-territorial organizations and bodies & $-0.006^{* *}$ & {$[0.003]$} & 0.006 & {$[0.021]$} & -0.004 & {$[0.020]$} \\
\hline \multicolumn{7}{|l|}{ Region: } \\
\hline Greater London & $\{\operatorname{Ref}\}$ & & $\{\operatorname{Ref}\}$ & & $\{\operatorname{Ref}\}$ & \\
\hline Remainder of South East & $-0.007 * *$ & {$[0.003]$} & $0.017^{* *}$ & {$[0.006]$} & $0.007 * *$ & {$[0.003]$} \\
\hline East Anglia & 0.010 & [0.017] & -0.001 & [0.009] & 0.006 & [0.004] \\
\hline South West & $-0.006^{*}$ & {$[0.004]$} & $0.019 * *$ & {$[0.009]$} & $0.009 * * *$ & {$[0.003]$} \\
\hline West Midlands & 0.004 & {$[0.012]$} & 0.003 & {$[0.010]$} & $0.006^{* *}$ & {$[0.003]$} \\
\hline East Midlands & -0.003 & {$[0.006]$} & 0.004 & {$[0.009]$} & -0.001 & {$[0.003]$} \\
\hline Yorkshire \& Humberside & -0.007 & {$[0.005]$} & 0.010 & {$[0.013]$} & -0.001 & {$[0.003]$} \\
\hline North West & -0.006 & {$[0.005]$} & 0.006 & [0.011] & -0.003 & [0.003] \\
\hline North & $-0.008 * * *$ & {$[0.003]$} & $0.021 *$ & {$[0.012]$} & 0.005 & [0.003] \\
\hline Wales & -0.006 & {$[0.006]$} & 0.012 & {$[0.011]$} & 0.004 & {$[0.003]$} \\
\hline Scotland & $-0.011 * * *$ & {$[0.004]$} & $0.027 *$ & {$[0.015]$} & $0.006^{* *}$ & {$[0.003]$} \\
\hline \multicolumn{7}{|l|}{ Waves: } \\
\hline Wave 3 & $\{\operatorname{Ref}\}\}$ & & & & & \\
\hline Wave 4 & $0.006^{*}$ & {$[0.004]$} & & 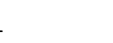 & & 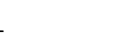 \\
\hline Wave 5 & 0.003 & {$[0.006]$} & & - & & - \\
\hline Wave 6 & 0.004 & {$[0.009]$} & & - & & - \\
\hline Wave 7 & 0.008 & {$[0.017]$} & & & & \\
\hline Wave 8 & 0.001 & {$[0.014]$} & & 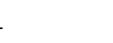 & & 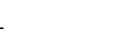 \\
\hline Wave 9 & 0.003 & {$[0.018]$} & & - & & - \\
\hline Wave 10 & 0.001 & {$[0.016]$} & & 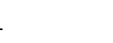 & & 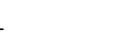 \\
\hline Wave 11 & -0.001 & {$[0.016]$} & & & & \\
\hline Wave 12 & 0.001 & {$[0.017]$} & & 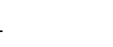 & & 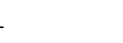 \\
\hline Wave 13 & 0.002 & {$[0.020]$} & & 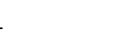 & & 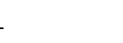 \\
\hline Wave 14 & 0.004 & {$[0.024]$} & & - & & 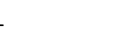 \\
\hline Wave 15 & -0.002 & {$[0.014]$} & & - & . & - \\
\hline Predicted Probability & $3.44 \%$ & & & & & \\
\hline \#Obs. [no. of individuals] & 28,026 & {$[5,169]$} & & & & \\
\hline Log-likelihood & $-4,121.5$ & & & & & \\
\hline Wald $\chi^{2}$ & $1863.0^{* * *}$ & & & & & \\
\hline $\operatorname{LR} \chi^{2}(\varrho=0)$ & $330.2^{* * *}$ & & & & & \\
\hline
\end{tabular}

Notes: ${ }^{*} \mathrm{p}<0.10,{ }^{* *} \mathrm{p}<0.05,{ }^{* * *} \mathrm{p}<0.01$. The specification also includes a constant term. The coefficients and standard errors of the permanent effects are derived from tests of the linear constraint that the summation of the level and the mean effect of each variable are equal to zero, e.g. $\beta_{\text {(Local Unemployment Rate) }}+\delta_{\text {(Local Unemployment Rate }}=0$. The marginal effects presented calculate the probability of a positive outcome, assuming that the random effect for that observation's panel is equal to zero. 


\section{Table 4: Dual Job Holding and Occupational Choice}

Two-stage Pooled OLS with bootstrapped standard errors

\begin{tabular}{|c|c|c|c|}
\hline \multirow{2}{*}{ Dependent variable: } & \multicolumn{3}{|c|}{ Different 2nd job } \\
\hline & [1-digit] & [2-digit] & [3-digit] \\
\hline \multirow{3}{*}{ Difference in hourly wage (primary occ. vs. next best) } & (1) & (2) & (ㄱ) \\
\hline & $-0.084 * * *$ & $-0.069 * *$ & -0.025 \\
\hline & {$[0.030]$} & [0.027] & {$[0.025]$} \\
\hline \multirow[t]{2}{*}{ Local unemployment rate } & 0.002 & 0.002 & 0.005 \\
\hline & {$[0.016]$} & [0.014] & {$[0.013]$} \\
\hline \multirow[t]{2}{*}{ Log (Equiv. annual household income in the last year) } & -0.038 & -0.032 & $-0.048 * *$ \\
\hline & {$[0.026]$} & [0.022] & {$[0.019]$} \\
\hline \multirow[t]{2}{*}{ Job satisfaction } & -0.004 & 0.004 & 0.002 \\
\hline & [0.007] & {$[0.006]$} & {$[0.006]$} \\
\hline \multirow{2}{*}{ Log(Labour market experience) } & 0.014 & 0.016 & $0.028^{* *}$ \\
\hline & [0.015] & [0.013] & {$[0.012]$} \\
\hline \multirow[t]{2}{*}{$\log ($ Occupational experience $)$} & $-0.034 * * *$ & $-0.043 * * *$ & $-0.026^{* *}$ \\
\hline & [0.013] & [0.011] & {$[0.010]$} \\
\hline \multirow{2}{*}{$\log ($ Tenure $)$} & 0.011 & $0.023^{* * *}$ & 0.005 \\
\hline & [0.011] & {$[0.009]$} & {$[0.008]$} \\
\hline \multirow[t]{2}{*}{ Wants to work more hours in primary job } & 0.026 & 0.001 & -0.007 \\
\hline & [0.032] & [0.028] & [0.026] \\
\hline Wants to work the same hours in primary occupation & $\{\operatorname{Ref}\}$. & $\{\operatorname{Ref}\}$. & $\{\operatorname{Ref}\}$. \\
\hline \multirow{2}{*}{ Wants to work less hours in primary job } & -0.009 & -0.001 & -0.003 \\
\hline & {$[0.020]$} & {$[0.018]$} & {$[0.017]$} \\
\hline \multirow[t]{2}{*}{ Log(Weekly hours in primary job) } & -0.016 & 0.031 & 0.02 \\
\hline & [0.036] & [0.034] & {$[0.032]$} \\
\hline \multirow[t]{2}{*}{ Log(Paid overtime hours) } & -0.008 & $-0.008^{*}$ & $-0.010^{* *}$ \\
\hline & {$[0.005]$} & {$[0.005]$} & {$[0.004]$} \\
\hline \multirow[t]{2}{*}{ Cohabiting/Married and spouse employed } & $-0.056^{* *}$ & -0.035 & $-0.043^{* *}$ \\
\hline & {$[0.024]$} & {$[0.022]$} & {$[0.020]$} \\
\hline \multirow{2}{*}{ Cohabiting/Married and spouse not employed } & $-0.169 * * *$ & $-0.139 * * *$ & $-0.099 * * *$ \\
\hline & {$[0.034]$} & [0.033] & {$[0.031]$} \\
\hline Single/Divorced & $\{\operatorname{Ref.}\}$ & $\{\operatorname{Ref}\}$. & $\{\operatorname{Ref}\}$ \\
\hline \multirow[t]{2}{*}{$\log ($ No. of children $)$} & -0.007 & -0.005 & -0.01 \\
\hline & {$[0.008]$} & {$[0.007]$} & {$[0.007]$} \\
\hline \multirow[t]{2}{*}{ Private Sector } & -0.047 & -0.015 & 0.005 \\
\hline & [0.032] & {$[0.028]$} & {$[0.026]$} \\
\hline \multirow[t]{2}{*}{ Permanent job } & 0.044 & -0.003 & -0.006 \\
\hline & {$[0.043]$} & {$[0.037]$} & {$[0.035]$} \\
\hline \multirow{2}{*}{ Promotion prospects in primary job } & $0.040 * *$ & 0.028 & 0.019 \\
\hline & {$[0.020]$} & {$[0.017]$} & {$[0.016]$} \\
\hline \multirow[t]{2}{*}{ Annual increments } & -0.015 & -0.006 & 0.009 \\
\hline & {$[0.020]$} & [0.017] & [0.016] \\
\hline High education & $\{\operatorname{Ref}\}$ & $\{\operatorname{Ref}\}$ & $\{\operatorname{Ref}\}$ \\
\hline \multirow[t]{2}{*}{ Middle education } & 0.032 & 0.001 & -0.039 \\
\hline & {$[0.030]$} & {$[0.027]$} & {$[0.024]$} \\
\hline \multirow[t]{2}{*}{ Low education } & $-0.063 *$ & -0.016 & -0.034 \\
\hline & {$[0.038]$} & {$[0.034]$} & {$[0.030]$} \\
\hline Mills Ratio & $0.064 *$ & $0.057^{*}$ & 0.046 \\
\hline & {$[0.036]$} & [0.033] & {$[0.031]$} \\
\hline Occupation (1-digit SOC codes): & & & \\
\hline Managers and administrators & $\{\operatorname{Ref}\}$ & $\{\operatorname{Ref}\}$ & $\{$ Ref. $\}$ \\
\hline
\end{tabular}

Table 4 continued in next page 


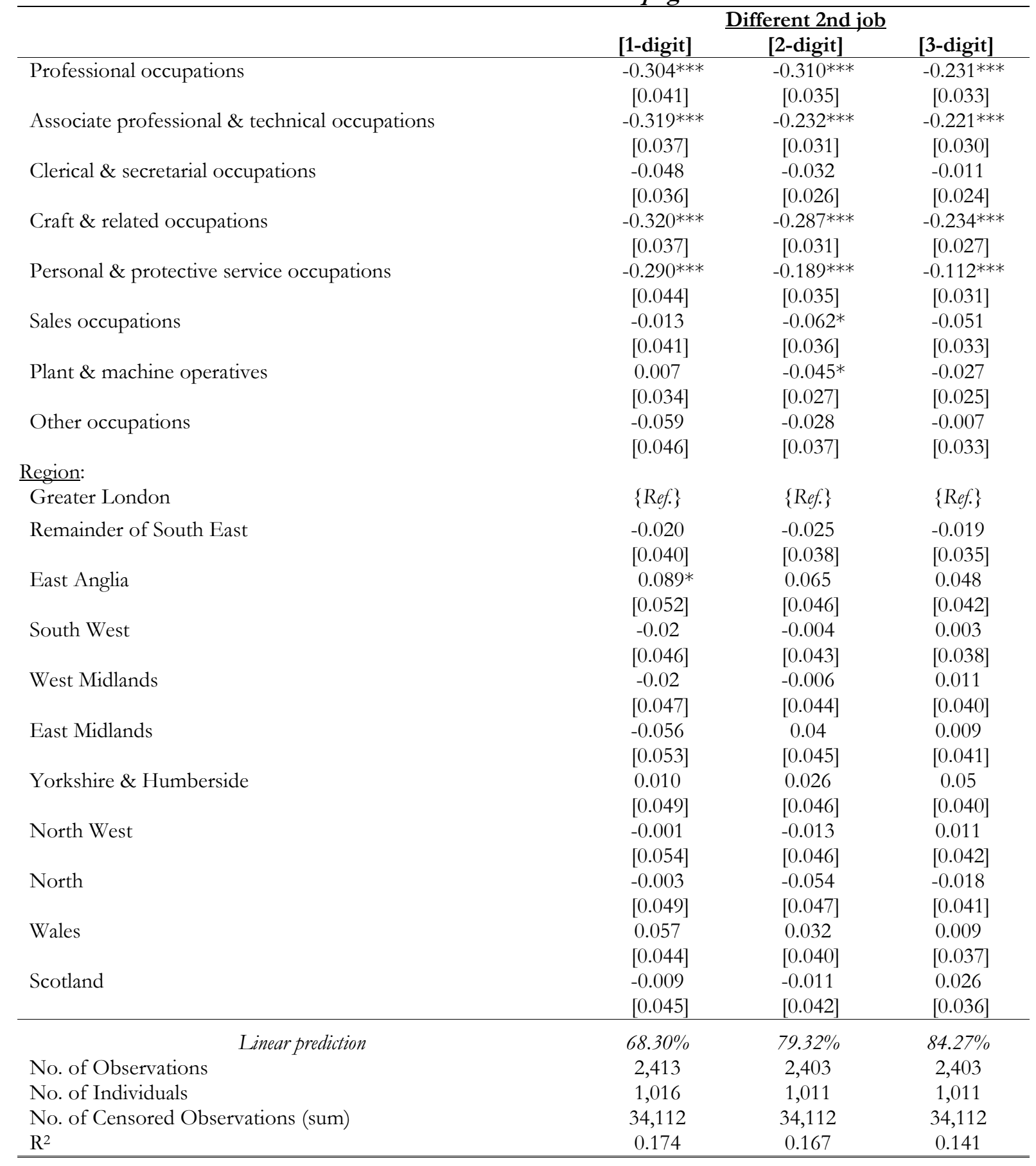

Notes: ${ }^{*} \mathrm{p}<0.10,{ }^{* *} \mathrm{p}<0.05,{ }^{* * *} \mathrm{p}<0.01$. The specification also includes industry and wave (year) fixed effects, along with a constant term. Coefficients and bootstrapped standard errors based on 1,000 replications are presented. The estimates presented are from $2^{\text {nd }}$ stage regressions. The $1^{\text {st }}$ stage is a selection equation for the decision to be a dual job-holder as proposed by Wooldridge (1995) and Semykina and Wooldridge (2005). In total, there are 34,112 censored observations in the $1^{\text {st }}$ stage (calculated as a summation of the number of censored observations in the 15 yearly regressions). 
Table 5: Job Mobility and Dual Job Holding

Random effects probit models

\begin{tabular}{|c|c|c|c|c|}
\hline $\begin{array}{c}\text { Dep. var: } \\
\text { Mobility }[\mathrm{t}+1] \text { into: }\end{array}$ & $\begin{array}{c}\text { (I) } \\
\text { Self- } \\
\text { employment } \\
\end{array}$ & $\begin{array}{c}\text { (II) } \\
\text { New } \\
\text { Employment } \\
\end{array}$ & $\begin{array}{c}\text { (III) } \\
\text { New } \\
\text { Position } \\
\end{array}$ & $\begin{array}{c}\text { (IV) } \\
\text { Unemployment } \\
\text { /Inactivity } \\
\end{array}$ \\
\hline \multicolumn{5}{|c|}{ Panel A: Moonlighting [main explanatory variable] } \\
\hline Moonlighter & $\begin{array}{l}(\underline{1}) \\
0.010^{* * *} \\
{[0.003]} \\
\end{array}$ & $\begin{array}{l}\quad(\underline{2}) \\
0.024^{* * *} \\
{[0.008]} \\
\end{array}$ & $\begin{array}{c}(\underline{3}) \\
0.001 \\
{[0.009]} \\
\end{array}$ & $\begin{array}{c}\underline{4}) \\
-0.004 * * * \\
{[0.002]} \\
\end{array}$ \\
\hline \multicolumn{5}{|c|}{ Panel B: Occupational choice in moonlighting [main explanatory variables] } \\
\hline Different [1-digit] SOC & $\begin{array}{c}(\underline{5}) \\
0.001 \\
{[0.002]}\end{array}$ & $\begin{array}{c}(\underline{6}) \\
0.014^{*} \\
{[0.008]}\end{array}$ & $\begin{array}{c}(\underline{7}) \\
-0.020 \\
{[0.016]} \\
(R \circ f)\end{array}$ & $\begin{array}{c}(\underline{8}) \\
0.001 \\
{[0.005]} \\
(R \circ f)\end{array}$ \\
\hline Same [1-digit] SOC & $\{\operatorname{Ref} \cdot\}$ & $\{$ Ref. $\}$ & $\{\operatorname{Ref}\}$. & $\{\operatorname{Ref}\}$. \\
\hline Non-moonlighter & $\begin{array}{c}-0.009 * * \\
{[0.004]}\end{array}$ & $\begin{array}{c}-0.031 * * \\
{[0.014]}\end{array}$ & $\begin{array}{l}-0.016 \\
{[0.016]}\end{array}$ & $\begin{array}{c}0.004 \\
{[0.003]}\end{array}$ \\
\hline Different [2-digit] SOC & $\begin{array}{c}(\underline{9}) \\
0.001 \\
{[0.002]}\end{array}$ & $\begin{array}{c}\underline{(10)} \\
0.018^{* *} \\
{[0.009]}\end{array}$ & $\begin{array}{c}(\underline{11}) \\
-0.038^{* *} \\
{[0.016]}\end{array}$ & $\begin{array}{c}(\underline{12}) \\
0.002 \\
{[0.007]}\end{array}$ \\
\hline Same [2-digit] SOC & $\{\operatorname{Ref} \cdot\}$ & $\{\operatorname{Ref}\}$ & $\{\operatorname{Ref}\}$. & $\{\operatorname{Ref} \cdot\}$ \\
\hline Non-moonlighter & $\begin{array}{l}-0.009 * \\
{[0.005]}\end{array}$ & $\begin{array}{c}-0.038^{* *} \\
{[0.018]}\end{array}$ & $\begin{array}{l}-0.038^{*} \\
{[0.021]}\end{array}$ & $\begin{array}{c}0.004 \\
{[0.004]}\end{array}$ \\
\hline Different [3-digit] SOC & $\begin{array}{c}(13) \\
0.001 \\
{[0.002]}\end{array}$ & $\begin{array}{c}(\underline{14}) \\
0.019 * * \\
{[0.009]}\end{array}$ & $\begin{array}{c}(\underline{15}) \\
-0.044 * * * \\
{[0.016]}\end{array}$ & $\begin{array}{c}(\underline{16}) \\
0.005 \\
{[0.010]}\end{array}$ \\
\hline Same [3-digit] SOC & $\{\operatorname{Ref}\}$. & $\{\operatorname{Ref}\}$. & $\{\operatorname{Ref}\}$. & $\{\operatorname{Ref}\}$. \\
\hline Non-moonlighter & $\begin{array}{l}-0.010^{*} \\
{[0.006]} \\
\end{array}$ & $\begin{array}{l}-0.036^{*} \\
{[0.020]} \\
\end{array}$ & $\begin{array}{l}-0.047 * \\
{[0.024]} \\
\end{array}$ & $\begin{array}{l}0.006 \\
{[0.004]} \\
\end{array}$ \\
\hline \multicolumn{5}{|l|}{ Panel C: Type of moonlighting } \\
\hline Serial moonlighter & $\begin{array}{c}(\underline{17}) \\
0.001 \\
{[0.002]}\end{array}$ & $\begin{array}{c}(\underline{18}) \\
-0.030 * * * \\
{[0.009]}\end{array}$ & $\begin{array}{l}(\underline{19}) \\
-0.009 \\
{[0.016]}\end{array}$ & $\begin{array}{c}(\underline{20}) \\
0.002 \\
{[0.005]}\end{array}$ \\
\hline Temporary moonlighter & $\{\operatorname{Ref} \cdot\}$ & $\{\operatorname{Ref} \cdot\}$ & $\{\operatorname{Ref} \cdot\}$ & $\{\operatorname{Ref}\}$. \\
\hline Non-moonlighter & $\begin{array}{c}-0.010^{* * *} \\
{[0.004]}\end{array}$ & $\begin{array}{c}-0.042^{* * *} \\
{[0.011]}\end{array}$ & $\begin{array}{l}-0.005 \\
{[0.012]}\end{array}$ & $\begin{array}{c}0.004^{*} \\
{[0.002]}\end{array}$ \\
\hline Model statistics [all models in each column] & (I) & (III) & (III) & 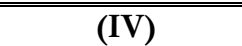 \\
\hline Pred. probability & 0.0097 & 0.1236 & 0.1434 & 0.0232 \\
\hline \# Observations & 22,268 & 25,136 & 25,758 & 22,501 \\
\hline \# Individuals & 4,815 & 5,061 & 5,047 & 4,869 \\
\hline
\end{tabular}

Notes: $\mathrm{p}<0.10, * * \mathrm{p}<0.05, * * * \mathrm{p}<0.01$. All cells present marginal effects and standard errors from random effects probit models. The specifications are identical to Table 3, with the addition of the logarithm of minutes of commuting to work in the $2^{\text {nd }}$ stage regressions. The specification of the $1^{\text {st }}$ stage regressions incorporates the difference in hourly wage (primary occ. vs. next best) in that of Table 3. 
Table 6: Job Mobility, Occupational Choice, and Dual Job Holding

Two-stage Pooled OLS with bootstrapped standard errors

\begin{tabular}{|c|c|c|c|c|c|c|c|c|c|}
\hline \multirow{2}{*}{$\begin{array}{c}\text { Dep. var:: } \\
\text { Different Occupation }_{[t+1]}\end{array}$} & \multicolumn{3}{|c|}{$\begin{array}{c}\text { (I) } \\
\text { Self-employment }\end{array}$} & \multicolumn{3}{|c|}{$\begin{array}{c}\text { (II) } \\
\text { New employment }\end{array}$} & \multicolumn{3}{|c|}{$\begin{array}{c}\text { (III) } \\
\text { New position }\end{array}$} \\
\hline & [1-digit] & [2-digit] & [3-digit] & [1-digit] & [2-digit] & [3-digit] & [1-digit] & [2-digit] & [3-digit] \\
\hline \multicolumn{10}{|l|}{ Panel A: Moonlighting } \\
\hline Moonlighter & $\begin{array}{c}(1) \\
0.068 \\
{[0.068]}\end{array}$ & $\begin{array}{c}(\underline{2}) \\
0.121^{*} \\
{[0.067]}\end{array}$ & $\begin{array}{c}(\underline{3}) \\
0.103 \\
{[0.065]}\end{array}$ & $\begin{array}{c}\underline{4}) \\
-0.006 \\
{[0.030]}\end{array}$ & $\begin{array}{c}\underline{5}) \\
-0.001 \\
{[0.028]}\end{array}$ & $\begin{array}{c}\underline{6}) \\
-0.001 \\
{[0.028]}\end{array}$ & $\begin{array}{c}(\underline{7}) \\
0.002 \\
{[0.033]}\end{array}$ & $\begin{array}{c}\underline{8}) \\
0.010 \\
{[0.032]}\end{array}$ & $\begin{array}{c}(\underline{9}) \\
0.015 \\
{[0.032]}\end{array}$ \\
\hline \multicolumn{10}{|c|}{ Panel B: Occupational choice in moonlighting } \\
\hline Different [1-digit] SOC & $\begin{array}{l}(\underline{10}) \\
0.578^{* * *} \\
{[0.105]}\end{array}$ & - & - & $\begin{array}{l}(\underline{11}) \\
0.165^{* * *} \\
{[0.058]}\end{array}$ & - & - & $\begin{array}{c}(\underline{12}) \\
0.091 \\
{[0.063]}\end{array}$ & - & - \\
\hline Same [1-digit] SOC & $\{\operatorname{Ref}\}$ & - & - & $\{\operatorname{Ref}\}$ & - & - & $\{R e f\}$. & - & - \\
\hline Non-moonlighter & $\begin{array}{l}0.318^{* * *} \\
{[0.083]}\end{array}$ & - & - & $\begin{array}{l}0.118^{* *} \\
{[0.048]} \\
\end{array}$ & - & - & $\begin{array}{l}0.061 \\
{[0.053]}\end{array}$ & - & - \\
\hline Different [2-digit] SOC & - & $\begin{array}{l}(\underline{13}) \\
0.280 * \\
{[0.144]}\end{array}$ & - & - & $\begin{array}{c}(\underline{14}) \\
0.219^{* * *} \\
{[0.066]}\end{array}$ & - & - & $\begin{array}{l}(\underline{15}) \\
0.169 * * \\
{[0.067]}\end{array}$ & - \\
\hline Same [2-digit] SOC & - & $\{\operatorname{Ref}\}$ & - & - & $\{\operatorname{Ref}\}$. & - & - & $\{\operatorname{Ref}\}$. & - \\
\hline Non-moonlighter & - & $\begin{array}{l}0.105 \\
{[0.134]}\end{array}$ & - & - & $\begin{array}{l}0.172 * * * \\
{[0.059]}\end{array}$ & - & - & $\begin{array}{l}0.120^{* *} \\
{[0.059]}\end{array}$ & - \\
\hline Different [3-digit] SOC & - & - & $\begin{array}{l}(\underline{16}) \\
0.315^{*} \\
{[0.163]}\end{array}$ & - & - & $\begin{array}{l}(\underline{17}) \\
0.301 * * * \\
{[0.072]}\end{array}$ & - & - & $\begin{array}{l}(\underline{18}) \\
0.140^{*} \\
{[0.076]}\end{array}$ \\
\hline Same [3-digit] SOC & - & - & $\{\operatorname{Ref}\}$. & - & - & $\{\operatorname{Ref}\}$. & - & - & $\{\operatorname{Ref}\}$ \\
\hline Non-moonlighter & - & - & $\begin{array}{l}0.159 \\
{[0.155]} \\
\end{array}$ & - & - & $\begin{array}{l}0.251 * * * \\
{[0.067]} \\
\end{array}$ & - & - & $\begin{array}{l}0.099 \\
{[0.071]} \\
\end{array}$ \\
\hline \multicolumn{10}{|l|}{ Panel C: Moonlighting type } \\
\hline $\begin{array}{l}\text { Serial moonlighter } \\
\text { Temporary moonlighter }\end{array}$ & $\begin{array}{l}(\underline{19}) \\
0.215^{*} \\
{[0.116]} \\
\{\text { Ref. }\}\end{array}$ & $\begin{array}{l}(\underline{20}) \\
0.081 \\
{[0.123]} \\
\{R e f .\}\end{array}$ & $\begin{array}{l}(\underline{21}) \\
0.133 \\
{[0.119]} \\
\{\operatorname{Ref} .\}\end{array}$ & $\begin{array}{l}(\underline{22}) \\
0.036 \\
{[0.060]} \\
\{R e f .\}\end{array}$ & $\begin{array}{l}(\underline{23}) \\
0.040 \\
{[0.061]} \\
\{\text { Ref. }\}\end{array}$ & $\begin{array}{l}(\underline{24}) \\
0.060 \\
{[0.060]} \\
\{\operatorname{Ref} .\}\end{array}$ & $\begin{array}{l}(\underline{25}) \\
0.054 \\
{[0.059]} \\
\{R e f .\}\end{array}$ & $\begin{array}{l}(\underline{26}) \\
0.047 \\
{[0.060]} \\
\{\text { Ref. }\}\end{array}$ & $\begin{array}{l}(\underline{27}) \\
0.020 \\
{[0.060]} \\
\{\text { Ref. }\}\end{array}$ \\
\hline Non-moonlighter & $\begin{array}{l}0.019 \\
{[0.085]} \\
\end{array}$ & $\begin{array}{l}-0.089 \\
{[0.086]} \\
\end{array}$ & $\begin{array}{l}-0.049 \\
{[0.085]} \\
\end{array}$ & $\begin{array}{l}0.018 \\
{[0.036]} \\
\end{array}$ & $\begin{array}{c}0.014 \\
{[0.034]} \\
\end{array}$ & $\begin{array}{l}0.021 \\
{[0.034]} \\
\end{array}$ & $\begin{array}{c}0.023 \\
{[0.043]} \\
\end{array}$ & $\begin{array}{l}0.012 \\
{[0.044]} \\
\end{array}$ & $\begin{array}{l}-0.005 \\
{[0.044]} \\
\end{array}$ \\
\hline \multicolumn{10}{|c|}{ Model statistics [all models in each column] } \\
\hline $\begin{array}{l}\text { Linear prediction } \\
\text { No. of observations } \\
\text { No. of uncensored observations }\end{array}$ & $\begin{array}{l}0.4536 \\
485 \\
22,415\end{array}$ & $\begin{array}{l}0.5732 \\
485 \\
22,415\end{array}$ & $\begin{array}{l}0.6144 \\
485 \\
22,415\end{array}$ & $\begin{array}{c}0.4787 \\
3,367 \\
22,415\end{array}$ & $\begin{array}{c}0.6099 \\
3,367 \\
22,415\end{array}$ & $\begin{array}{c}0.6537 \\
3,367 \\
22,415\end{array}$ & $\begin{array}{c}0.4053 \\
3,989 \\
22,415\end{array}$ & $\begin{array}{c}0.5301 \\
3,989 \\
22,415\end{array}$ & $\begin{array}{c}0.5772 \\
3,989 \\
22,415\end{array}$ \\
\hline
\end{tabular}

Notes: ${ }^{*} \mathrm{p}<0.10,{ }^{*} \mathrm{p}<0.05,{ }^{* * *} \mathrm{p}<0.01$. Coefficients and bootstrapped standard errors from two-stage pooled OLS models. The 1 st stage models are three sets of selection equations for the decision to change job in the next year (a) into self-employment, (b) new employment, and (c) new position with the same employer (the comparison group comprises of individuals staying in the same job in the next year). The number of uncensored observations in the first stage is calculated as the summation of the number of censored observations in the three sets of 14 yearly regressions. All remaining information is provided in Table A2 in the Appendix. 
Table 7: Job Mobility, Outcomes, and Dual Job Holding

Two-stage Pooled OLS with bootstrapped standard errors

\begin{tabular}{|c|c|c|c|c|c|c|c|c|c|}
\hline \multirow[b]{2}{*}{ Dep. var: } & \multicolumn{3}{|c|}{$\underline{\text { Self-employment }}$} & \multicolumn{3}{|c|}{ New job } & \multicolumn{3}{|c|}{ New position } \\
\hline & $\begin{array}{c}\% \text { month. } \\
\text { wage } \\
\text { difference }\end{array}$ & $\begin{array}{l}\text { Upward } \\
\text { wage } \\
\text { mobility }\end{array}$ & $\begin{array}{l}\text { Upward } \\
\text { skill } \\
\text { mobility }\end{array}$ & $\begin{array}{c}\% \text { month. } \\
\text { wage } \\
\text { difference }\end{array}$ & $\begin{array}{l}\text { Upward } \\
\text { wage } \\
\text { mobility }\end{array}$ & $\begin{array}{l}\text { Upward } \\
\text { skill } \\
\text { mobility }\end{array}$ & $\begin{array}{c}\text { \% month. } \\
\text { wage } \\
\text { difference }\end{array}$ & $\begin{array}{l}\text { Upward } \\
\text { wage } \\
\text { mobility }\end{array}$ & $\begin{array}{l}\text { Upward } \\
\text { skill } \\
\text { mobility }\end{array}$ \\
\hline \multicolumn{10}{|l|}{ Panel A: Moonlighting } \\
\hline Moonlighter & $\begin{array}{l}(\underline{\mathrm{A} 1}) \\
0.121 \\
{[0.118]}\end{array}$ & $\begin{array}{c}(\underline{\mathrm{A} 2}) \\
0.090 \\
{[0.178]} \\
\end{array}$ & $\begin{array}{c}(\underline{\mathrm{A} 3}) \\
0.012 \\
{[0.046]} \\
\end{array}$ & $\begin{array}{c}(\underline{\mathrm{A} 4}) \\
0.040^{* *} \\
{[0.016]} \\
\end{array}$ & $\begin{array}{c}(\underline{\mathrm{A} 5}) \\
0.065^{* *} \\
{[0.030]} \\
\end{array}$ & $\begin{array}{c}(\underline{\mathrm{A} 6}) \\
0.027 \\
{[0.022]} \\
\end{array}$ & $\begin{array}{c}(\underline{\mathrm{A} 7}) \\
0.019 \\
{[0.014]} \\
\end{array}$ & $\begin{array}{c}(\underline{\mathrm{A} 8}) \\
0.048 \\
{[0.032]}\end{array}$ & $\begin{array}{l}(\underline{\mathrm{A} 9}) \\
-0.006 \\
{[0.021]} \\
\end{array}$ \\
\hline \multicolumn{10}{|c|}{ Panel B: Occupational choice in moonlighting } \\
\hline Different occupation [1-digit] & $\begin{array}{l}\underline{\mathrm{B} 1}) \\
0.077 \\
{[0.260]} \\
-0.066 \\
{[0.225]}\end{array}$ & $\begin{array}{l}\underline{B} 2) \\
0.106 \\
{[0.414]} \\
-0.013 \\
{[0.374]}\end{array}$ & $\begin{array}{c}(\underline{\mathrm{B} 3}) \\
0.219^{* * *} \\
{[0.084]} \\
0.134^{* *} \\
{[0.062]}\end{array}$ & $\begin{array}{c}\underline{\mathrm{B} 4}) \\
0.036 \\
{[0.035]} \\
-0.064^{* *} \\
{[0.029]} \\
\end{array}$ & $\begin{array}{c}\underline{(\mathrm{B} 5)} \\
0.037 \\
{[0.064]} \\
-0.090^{*} \\
{[0.054]}\end{array}$ & $\begin{array}{c}\underline{\mathrm{B} 6}) \\
0.124^{* * *} \\
{[0.040]} \\
0.057^{*} \\
{[0.030]}\end{array}$ & $\begin{array}{c}(\underline{\mathrm{B} 7}) \\
0.040 \\
{[0.029]} \\
0.008 \\
{[0.026]}\end{array}$ & $\begin{array}{c}\underline{\mathrm{B} 8}) \\
0.076 \\
{[0.063]} \\
0.004 \\
{[0.054]}\end{array}$ & $\begin{array}{c}(\underline{B} 9) \\
0.057 \\
{[0.038]} \\
0.045 \\
{[0.029]}\end{array}$ \\
\hline Different occupation [2-digit] & $\begin{array}{l}(\underline{B 10}) \\
0.217 \\
{[0.360]} \\
0.069 \\
{[0.355]}\end{array}$ & $\begin{array}{c}(\underline{\mathrm{B} 11}) \\
0.245 \\
{[0.625]} \\
0.125 \\
{[0.617]}\end{array}$ & $\begin{array}{c}(\underline{\mathrm{B} 12}) \\
0.085 \\
{[0.094]} \\
0.057 \\
{[0.083]}\end{array}$ & $\begin{array}{c}(\underline{B 13}) \\
0.061 \\
{[0.040]} \\
-0.088^{* *} \\
{[0.036]}\end{array}$ & $\begin{array}{c}(\underline{B 14}) \\
0.115 \\
{[0.073]} \\
-0.156^{* *} \\
{[0.065]}\end{array}$ & $\begin{array}{c}(\underline{\mathrm{B} 15}) \\
0.075^{*} \\
{[0.045]} \\
0.031 \\
{[0.039]}\end{array}$ & $\begin{array}{l}(\underline{B 16}) \\
0.022 \\
{[0.033]} \\
-0.003 \\
{[0.030]}\end{array}$ & $\begin{array}{l}(\underline{B 17}) \\
0.042 \\
{[0.069]} \\
-0.016 \\
{[0.062]}\end{array}$ & $\begin{array}{c}(\underline{\mathrm{B} 18}) \\
0.074 * * \\
{[0.036]} \\
0.062 * * \\
{[0.027]}\end{array}$ \\
\hline Different occupation [3-digit] & $\begin{array}{l}(\underline{B} 19) \\
0.217 \\
{[0.360]} \\
0.069 \\
{[0.355]}\end{array}$ & $\begin{array}{c}\underline{B} 20) \\
0.245 \\
{[0.625]} \\
0.125 \\
{[0.617]}\end{array}$ & $\begin{array}{c}\underline{B} 21) \\
0.034 \\
{[0.100]} \\
0.016 \\
{[0.089]}\end{array}$ & $\begin{array}{l}(\underline{B} 22) \\
0.028 \\
{[0.045]} \\
-0.064 \\
{[0.041]}\end{array}$ & $\begin{array}{l}\underline{B} 23) \\
0.022 \\
{[0.082]} \\
-0.084 \\
{[0.075]}\end{array}$ & $\begin{array}{c}\underline{B} 24) \\
0.084 * \\
{[0.049]} \\
0.043 \\
{[0.043]}\end{array}$ & $\begin{array}{c}(\underline{B} 25) \\
0.028 \\
{[0.036]} \\
0.003 \\
{[0.034]}\end{array}$ & $\begin{array}{c}\underline{B 26}) \\
0.065 \\
{[0.075]} \\
0.004 \\
{[0.069]}\end{array}$ & $\begin{array}{c}\underline{B} 27) \\
0.051 \\
{[0.039]} \\
0.047 \\
{[0.033]}\end{array}$ \\
\hline Moonli & & & & & & & & & \\
\hline Serial moonlighter & $\begin{array}{c}(\underline{\mathrm{C} 1}) \\
0.326 \\
{[0.224]} \\
0.046 \\
{[0.150]}\end{array}$ & $\begin{array}{c}(\underline{\mathrm{C} 2}) \\
0.374 \\
{[0.336]} \\
0.103 \\
{[0.241]}\end{array}$ & $\begin{array}{l}(\underline{\mathrm{C} 3}) \\
-0.036 \\
{[0.094]} \\
-0.027 \\
{[0.058]}\end{array}$ & $\begin{array}{c}(\underline{\mathrm{C} 4}) \\
0.056^{*} \\
{[0.034]} \\
-0.022 \\
{[0.020]}\end{array}$ & $\begin{array}{l}(\underline{\mathrm{C} 5}) \\
0.058 \\
{[0.062]} \\
-0.047 \\
{[0.036]}\end{array}$ & $\begin{array}{l}(\underline{\mathrm{C} 6}) \\
0.068 \\
{[0.047]} \\
-0.005 \\
{[0.026]}\end{array}$ & $\begin{array}{l}(\underline{\mathrm{C} 7}) \\
-0.025 \\
{[0.026]} \\
-0.031 \\
{[0.020]}\end{array}$ & $\begin{array}{c}(\underline{\mathrm{C} 8}) \\
-0.030 \\
{[0.061]} \\
-0.062 \\
{[0.042]}\end{array}$ & $\begin{array}{c}(\underline{\mathrm{C} 9}) \\
0.078^{*} \\
{[0.042]} \\
0.042 \\
{[0.026]}\end{array}$ \\
\hline loder statistics [all modeis in & Corumn] & & & & & & & & \\
\hline $\begin{array}{c}\text { Linear prediction } \\
\text { No. of observations } \\
\text { No. of uncensored observations }\end{array}$ & $\begin{array}{c}0.0192 \\
166 \\
22,415\end{array}$ & $\begin{array}{c}0.3193 \\
166 \\
22,415\end{array}$ & $\begin{array}{c}0.1814 \\
485 \\
22,415 \\
\end{array}$ & $\begin{array}{l}0.094 \\
3,265 \\
22,415 \\
\end{array}$ & $\begin{array}{c}0.3798 \\
3,265 \\
22,415\end{array}$ & $\begin{array}{c}0.1449 \\
3,367 \\
22,415\end{array}$ & $\begin{array}{c}0.0911 \\
3,886 \\
22,415\end{array}$ & $\begin{array}{c}0.3178 \\
3,886 \\
22,415\end{array}$ & $\begin{array}{c}0.1589 \\
3,989 \\
22,415\end{array}$ \\
\hline
\end{tabular}

Notes: $* \mathrm{p}<0.10, * * \mathrm{p}<0.05, * * * \mathrm{p}<0.01$. Coefficients and bootstrapped standard errors from two-stage pooled OLS models. The $1^{\text {st }}$ stage models are three sets of selection equations for the decision to change job in the next year (a) into self-employment, (b) new employment, and (c) new position with the same employer (the comparison group comprises of individuals staying in the same job in the next year). The number of uncensored observations in the first stage is calculated as the summation of the number of censored observations in the three sets of 14 yearly regressions. There are only 166 observations on the wage outcomes of the self-employed, as this information is obtained from a different question addressing only the self-employed in the BHPS. The variable entailed a large number of missing responses. 


\section{Appendix:}

\section{A) Derivation of Proposition}

From equations (2) and (3) we can derive the necessary condition for $\Delta_{1}>\Delta_{2}$ :

$$
\begin{gathered}
\Delta_{1}>\Delta_{2}=>\left(1-\gamma^{i j}\right) C^{i}>\left(1-\gamma^{k j}\right)\left(c^{k}+\gamma^{i k} C^{i}\right) \Rightarrow \\
\left(1-\gamma^{i j}\right) C^{i}-\left(1-\gamma^{k j}\right) \gamma^{i k} C^{i}>\left(1-\gamma^{k j}\right) c^{k} \Rightarrow \\
\left(1-\gamma^{i j}+\gamma^{k j} \gamma^{i k}-\gamma^{i k}\right) C^{i}>\left(1-\gamma^{k j}\right) c^{k}
\end{gathered}
$$

Given that $0<\gamma^{k j}<1, c^{k}>0$, and $C^{i}>0$, it must be true that:

$$
\begin{gathered}
1-\gamma^{i j}+\gamma^{k j} \gamma^{i k}-\gamma^{i k}>0 \Rightarrow \\
1-\gamma^{i j}>\gamma^{i k}-\gamma^{k j} \Rightarrow \\
1-\gamma^{i j}>\left(1-\gamma^{k j}\right) \gamma^{i k} \Rightarrow \\
\frac{1-\gamma^{i j}}{1-\gamma^{k j}}>\gamma^{i k}
\end{gathered}
$$

This condition A1 will always hold when:

$$
\gamma^{k j}>\gamma^{i j}
$$

because then

$$
\frac{1-\gamma^{i j}}{1-\gamma^{k j}}>1
$$

Since $0<\gamma^{i k}<1$, it is always true that

$$
\frac{1-\gamma^{i j}}{1-\gamma^{k j}}>1>\gamma^{i k}
$$

which confirms that when $\gamma^{k j}>\gamma^{i j}$, then $\Delta_{1}>\Delta_{2}$.

\section{B) Calculation of the difference in earnings (primary occupation vs. next best alternative) variable}

The best alternative occupation is detected based on an equation describing the occupational choice in the second job, using a multinomial probit model. Specifically, we let $y_{2 j}$ denote the individual occupational choice of the second job, where $y_{2 j}$ can take the unordered multinomial values $j=\{0,1, \ldots, 9\}$ reflecting the 9 
different 1-digit SOC groups. We then investigate how the set of conditioning variables $\boldsymbol{v}=\left\{y_{1 j}\right.$, $\left.\boldsymbol{x}\right\}$, where $y_{1 j}$ is the occupation of the individual in the primary job and $\boldsymbol{x}$ captures other demographic and primary jobspecific variables, affect the probability of secondary-job selection, $P\left(y_{2 j}=j \mid \boldsymbol{v}\right)$, ceteris paribus.

Based on the estimates of this model, the predicted probabilities of occupational choice in the second job, conditional on the occupation of the primary job, are shown in Table A1. The best alternative occupations can be easily obtained by looking across each row of Table $A 1$ and selecting the cell with the highest predicted probability, excluding the elements of the diagonal. In doing so, it is evident that, for example, the best alternative occupation in the secondary job for those currently employed as Professional occupations in their primary job is an Associated Professional and Technical occupation.

Utilizing the information of Table A1, the predicted wages from the best alternative occupation are hence calculated based on an hourly wage equation model:

$$
\ln w_{i t}=x_{i t}^{\prime} \beta+\zeta y_{1(j) i t}+g_{i t}
$$

where, for instance, the predicted wage for Managers or Administrators (SOC code 2) is obtained as $\ln \widehat{w}_{i t(2)}=x_{i t}^{\prime} \hat{\beta}+\hat{\zeta} y_{1(3) i t}$, which is the wage the individuals would receive if they were employed in the next best category of Associated Professional and Technical occupation instead (SOC code 3).

The difference in the earnings capacity between the current and the best alternative occupation is thus calculated as the difference between the wages received from the current occupation in the primary job and The predicted wages from the best alternative occupation in the second job.

\section{C) Presentation of full estimates of the models of Panel $A$ in Tables 5 and 6}

Table A1: Occupational Transitions between $1^{\text {st }}$ and $2^{\text {nd }}$ job: Predicted Probabilities

\begin{tabular}{|c|c|c|c|c|c|c|c|c|c|c|}
\hline & $2^{\text {nd }}$ Job & $\begin{array}{c}\text { Group } 1 \\
\text { Manag. }\end{array}$ & $\begin{array}{c}\text { Group } 2 \\
\text { Profess. }\end{array}$ & $\begin{array}{l}\text { Group } 3 \\
\text { Associate }\end{array}$ & $\begin{array}{r}\text { Group } 4 \\
\text { Clerical }\end{array}$ & $\begin{array}{l}\text { Group } \\
\text { Craft }\end{array}$ & $\begin{array}{c}\text { Group } 6 \\
\text { Personal }\end{array}$ & $\begin{array}{r}\text { Group } \\
\text { Sales }\end{array}$ & $\begin{array}{r}\text { Group } \\
\text { Plant }\end{array}$ & $\begin{array}{c}\text { Group } 9 \\
\text { Other }\end{array}$ \\
\hline Group & Managers \& administrators & $17.2 \%$ & $11.7 \%$ & $21.0 \%$ & $5.8 \%$ & $8.3 \%$ & $22.2 \%$ & $4.2 \%$ & $3.5 \%$ & $6.2 \%$ \\
\hline Group & Professional occupations & $7.9 \%$ & $36.2 \%$ & $34.2 \%$ & $1.7 \%$ & $2.4 \%$ & $9.7 \%$ & $1.9 \%$ & $2.9 \%$ & $3.2 \%$ \\
\hline Group & Clerical \& secretarial occupations & $2.5 \%$ & $2.2 \%$ & $24.8 \%$ & $12.5 \%$ & $12.5 \%$ & $20.5 \%$ & $4.7 \%$ & $6.0 \%$ & $14.5 \%$ \\
\hline Group & Craft \& related occupations & $3.8 \%$ & $1.0 \%$ & $8.3 \%$ & $0.5 \%$ & $48.4 \%$ & $17.9 \%$ & $0.7 \%$ & $7.6 \%$ & $11.8 \%$ \\
\hline Group & Plant \& machine operatives & $2.4 \%$ & $1.1 \%$ & $19.2 \%$ & $3.3 \%$ & $15.0 \%$ & $27.0 \%$ & $3.2 \%$ & $14.3 \%$ & $14.6 \%$ \\
\hline Group & Other occupations & $7.9 \%$ & $1.5 \%$ & $11.6 \%$ & $1.1 \%$ & $22.4 \%$ & $25.0 \%$ & $2.9 \%$ & $5.5 \%$ & $22.1 \%$ \\
\hline
\end{tabular}

Notes: The Table consists of predicted probabilities of $2^{\text {nd }}$ job occupational choice, conditional on $1^{\text {st }}$ job occupational choice, based on estimates of a Multinomial Probit model (available from the authors upon request). 
Table A2: Job Mobility, Occupational Choice, and Dual Job Holding

\begin{tabular}{|c|c|c|c|c|c|c|c|}
\hline \multirow[t]{2}{*}{$\frac{\text { Sample }}{\text { Dependent Variable: }}$} & (A) & \multicolumn{3}{|c|}{ Random Effects Probit } & \multicolumn{3}{|c|}{$\begin{array}{l}\text { (B) Linear Probability Model } \\
\text { with selectivity correction } \\
\text { Job Switchers } \\
\text { Different occupation in: }\end{array}$} \\
\hline & $\begin{array}{l}\text { Self- } \\
\text { Emp. }\end{array}$ & $\begin{array}{l}\text { New } \\
\text { Job }\end{array}$ & $\begin{array}{c}\text { New } \\
\text { Position } \\
\end{array}$ & $\begin{array}{c}\text { Not } \\
\text { Employed }\end{array}$ & $\begin{array}{l}\text { Self- } \\
\text { Emp. }\end{array}$ & $\begin{array}{l}\text { New } \\
\text { Job }\end{array}$ & $\begin{array}{c}\text { New } \\
\text { Position }\end{array}$ \\
\hline \multirow{3}{*}{ Moonlighter } & (㞷1) & $(\underline{A} 2)$ & $(\underline{\mathrm{A} 3})$ & $(\underline{\mathrm{A} 4})$ & (B1) & (B2) & $(\underline{B} 3)$ \\
\hline & $0.010^{* * *}$ & $0.024 * * *$ & 0.001 & $-0.004 *$ & 0.068 & -0.006 & 0.002 \\
\hline & {$[0.003]$} & {$[0.008]$} & [0.009] & {$[0.002]$} & {$[0.068]$} & {$[0.030]$} & {$[0.033]$} \\
\hline \multirow[t]{2}{*}{ Local unemployment rate } & 0.001 & -0.026 & -0.044 & -0.008 & 0.123 & -0.150 & -0.075 \\
\hline & {$[0.006]$} & {$[0.043]$} & [0.054] & {$[0.015]$} & [0.545] & {$[0.213]$} & [0.202] \\
\hline \multirow[t]{2}{*}{ Log (Equiv. annual household income last year) } & 0.001 & $-0.017 * * *$ & -0.008 & $-0.010^{* * *}$ & 0.009 & $-0.046 * *$ & -0.008 \\
\hline & {$[0.001]$} & {$[0.004]$} & {$[0.006]$} & {$[0.002]$} & {$[0.050]$} & {$[0.018]$} & {$[0.017]$} \\
\hline \multirow[t]{2}{*}{ Job satisfaction } & $-0.001 * * *$ & $-0.027 * * *$ & $-0.014 * * *$ & $-0.004 * * *$ & $-0.052 * * *$ & $-0.024 * * *$ & $-0.015^{* *}$ \\
\hline & {$[0.000]$} & {$[0.001]$} & {$[0.002]$} & {$[0.001]$} & {$[0.016]$} & {$[0.005]$} & {$[0.006]$} \\
\hline \multirow[t]{2}{*}{ Log(Labour market experience $)$} & -0.001 & $-0.037 * * *$ & $-0.039 * * *$ & 0.001 & 0.027 & $-0.029 * *$ & 0.001 \\
\hline & {$[0.000]$} & {$[0.003]$} & {$[0.004]$} & {$[0.001]$} & [0.035] & {$[0.013]$} & [0.012] \\
\hline \multirow[t]{2}{*}{ Log(Occupational experience) } & -0.001 & -0.001 & 0.002 & $0.002 *$ & $-0.086^{* * *}$ & $-0.081 * * *$ & $-0.071 * * *$ \\
\hline & {$[0.000]$} & {$[0.003]$} & {$[0.003]$} & {$[0.001]$} & {$[0.031]$} & {$[0.013]$} & {$[0.012]$} \\
\hline \multirow[t]{2}{*}{$\log ($ Tenure $)$} & $-0.002 * * *$ & $-0.061 * * *$ & $-0.044 * * *$ & $-0.005^{* * *}$ & -0.007 & $0.022 *$ & $0.027 * * *$ \\
\hline & {$[0.001]$} & {$[0.003]$} & {$[0.003]$} & {$[0.001]$} & {$[0.024]$} & {$[0.013]$} & {$[0.010]$} \\
\hline \multirow[t]{2}{*}{ Wants to work more hours } & 0.001 & $0.023 * * *$ & $0.024^{* *}$ & 0.002 & -0.145 & $-0.055^{*}$ & 0.038 \\
\hline & {$[0.001]$} & {$[0.008]$} & {$[0.010]$} & {$[0.002]$} & [0.089] & {$[0.030]$} & [0.029] \\
\hline Wants to work the same hours & $\{\operatorname{Ref}\}$. & $\{\operatorname{Ref}\}$. & $\{\operatorname{Ref}\}$. & $\{\operatorname{Ref}\}$. & $\{\operatorname{Ref.}\}$ & $\{\operatorname{Ref}\}$. & $\{\operatorname{Ref}:\}$ \\
\hline \multirow[t]{2}{*}{ Wants to work less hours } & -0.001 & -0.004 & -0.007 & -0.001 & -0.031 & 0.01 & -0.002 \\
\hline & {$[0.001]$} & {$[0.004]$} & {$[0.005]$} & {$[0.001]$} & {$[0.046]$} & [0.019] & {$[0.017]$} \\
\hline \multirow[t]{2}{*}{ Log(Weekly hours in primary job) } & 0.001 & $0.034 * * *$ & -0.009 & -0.004 & -0.102 & $-0.119 * * *$ & $-0.070^{*}$ \\
\hline & {$[0.001]$} & {$[0.009]$} & {$[0.011]$} & {$[0.003]$} & {$[0.081]$} & {$[0.039]$} & {$[0.037]$} \\
\hline \multirow[t]{2}{*}{ Log(Paid overtime hours) } & $-0.000^{* *}$ & 0.001 & $0.002 *$ & $-0.001 * * *$ & -0.009 & 0.002 & $-0.010 * *$ \\
\hline & {$[0.000]$} & {$[0.001]$} & {$[0.001]$} & {$[0.000]$} & {$[0.013]$} & {$[0.004]$} & {$[0.004]$} \\
\hline \multirow[t]{2}{*}{ Cohabiting/Married and spouse employed } & 0.001 & 0.006 & 0.001 & $-0.012 * * *$ & 0.044 & 0.007 & $0.056^{* * *}$ \\
\hline & {$[0.001]$} & {$[0.005]$} & {$[0.006]$} & {$[0.002]$} & {$[0.067]$} & {$[0.023]$} & {$[0.020]$} \\
\hline \multirow[t]{2}{*}{ Cohabiting/Married and spouse not employed } & 0.001 & 0.004 & 0.009 & $-0.005^{* * *}$ & 0.081 & -0.019 & $0.069 * *$ \\
\hline & {$[0.001]$} & {$[0.007]$} & [0.009] & {$[0.002]$} & {$[0.085]$} & {$[0.031]$} & {$[0.028]$} \\
\hline Single/Divorced & $\{\operatorname{Ref}\}$. & $\{\operatorname{Ref}\}$. & $\{\operatorname{Ref}:\}$ & $\{\operatorname{Ref}\}$. & $\{\operatorname{Ref}\}$. & $\{\operatorname{Ref}\}$. & $\{\operatorname{Ref}\}$. \\
\hline \multirow[t]{2}{*}{ Log(No. of children) } & 0.001 & -0.001 & 0.002 & -0.001 & -0.018 & 0.001 & -0.006 \\
\hline & {$[0.000]$} & {$[0.002]$} & [0.002] & {$[0.000]$} & [0.018] & {$[0.007]$} & {$[0.006]$} \\
\hline High education & $\{\operatorname{Ref}\}$. & $\{\operatorname{Ref}\}$. & $\{\operatorname{Ref}\}$. & $\{\operatorname{Ref}\}$. & $\{\operatorname{Ref}\}$. & $\{\operatorname{Ref}\}$. & $\{\operatorname{Ref} \cdot\}$ \\
\hline \multirow[t]{2}{*}{ Middle education } & 0.001 & $0.015^{* *}$ & -0.010 & $0.006^{* *}$ & 0.077 & $0.080 * * *$ & 0.005 \\
\hline & {$[0.001]$} & {$[0.006]$} & {$[0.007]$} & {$[0.002]$} & [0.068] & {$[0.027]$} & {$[0.022]$} \\
\hline \multirow[t]{2}{*}{ Low education } & -0.001 & $0.037 * * *$ & $-0.022 * *$ & $0.014 * * *$ & 0.052 & $0.076^{* *}$ & 0.031 \\
\hline & {$[0.001]$} & {$[0.010]$} & {$[0.009]$} & {$[0.005]$} & [0.091] & {$[0.034]$} & [0.032] \\
\hline Occupation (1-digit SOC codes): & & & & & & & \\
\hline Managers and administrators & $\{\operatorname{Ref} \cdot\}$ & $\{\operatorname{Ref} \cdot\}$ & $\{R e f \cdot\}$ & $\{\operatorname{Ref}\}$ & $\{\operatorname{Ref} \cdot\}$ & $\{\operatorname{Ref} \cdot\}$ & $\{\operatorname{Ref} \cdot\}$ \\
\hline Professional & -0.001 & 0.003 & $-0.022^{* * *}$ & -0.003 & -0.012 & -0.031 & $0.153^{* * *}$ \\
\hline & {$[0.001]$} & {$[0.008]$} & {$[0.008]$} & {$[0.002]$} & [0.102] & {$[0.040]$} & {$[0.031]$} \\
\hline Associate professional \& technical & $-0.001 *$ & -0.008 & $-0.028 * * *$ & $-0.004 *$ & -0.032 & -0.013 & $0.252^{* * *}$ \\
\hline & {$[0.001]$} & {$[0.007]$} & {$[0.007]$} & {$[0.002]$} & {$[0.095]$} & {$[0.037]$} & {$[0.029]$} \\
\hline Clerical \& secretarial & $-0.003^{* * *}$ & -0.007 & -0.001 & $-0.005^{* *}$ & $0.518^{* * *}$ & 0.015 & $0.246^{* * *}$ \\
\hline & {$[0.001]$} & {$[0.007]$} & {$[0.009]$} & {$[0.002]$} & {$[0.085]$} & {$[0.036]$} & {$[0.029]$} \\
\hline
\end{tabular}

Table A2 continued in next page 
Table A2 continued from last page

\begin{tabular}{|c|c|c|c|c|c|c|c|}
\hline Craft \& related & $\begin{array}{c}(\underline{\mathrm{A} 1}) \\
-0.001 \\
{[0.001]}\end{array}$ & $\begin{array}{c}(\underline{\mathrm{A} 2}) \\
-0.009 \\
{[0.007]}\end{array}$ & $\begin{array}{c}(\underline{\mathrm{A} 3}) \\
-0.059 * * * \\
{[0.007]}\end{array}$ & $\begin{array}{c}(\underline{\mathrm{A} 4}) \\
0.001 \\
{[0.003]}\end{array}$ & $\begin{array}{c}(\underline{\mathrm{B} 1}) \\
-0.139 * \\
{[0.073]}\end{array}$ & $\begin{array}{c}(\underline{\mathrm{B} 2}) \\
-0.120^{* * *} \\
{[0.033]}\end{array}$ & $\begin{array}{c}\underline{(\mathrm{B} 3)} \\
0.219^{* * *} \\
{[0.031]}\end{array}$ \\
\hline Personal \& protective service & $\begin{array}{l}-0.002^{* *} \\
{[0.001]}\end{array}$ & $\begin{array}{l}-0.001 \\
{[0.010]}\end{array}$ & $\begin{array}{c}-0.024 * * \\
{[0.010]}\end{array}$ & $\begin{array}{l}0.006 \\
{[0.004]}\end{array}$ & $\begin{array}{l}0.457 * * * \\
{[0.120]}\end{array}$ & $\begin{array}{l}-0.068 \\
{[0.044]}\end{array}$ & $\begin{array}{l}0.115^{* * *} \\
{[0.037]}\end{array}$ \\
\hline Sales occupations & $\begin{array}{l}-0.001 \\
{[0.001]}\end{array}$ & $\begin{array}{l}0.032^{* * *} \\
{[0.011]}\end{array}$ & $\begin{array}{l}-0.016 \\
{[0.010]}\end{array}$ & $\begin{array}{c}0.003 \\
{[0.004]}\end{array}$ & $\begin{array}{l}0.222^{* *} \\
{[0.099]}\end{array}$ & $\begin{array}{l}0.077 * * \\
{[0.039]}\end{array}$ & $\begin{array}{l}0.374^{* * *} \\
{[0.037]}\end{array}$ \\
\hline Plant \& machine operatives & $\begin{array}{c}-0.002 * * * \\
{[0.001]}\end{array}$ & $\begin{array}{l}-0.002 \\
{[0.007]}\end{array}$ & $\begin{array}{c}-0.050 * * * \\
{[0.007]}\end{array}$ & $\begin{array}{c}0.001 \\
{[0.002]}\end{array}$ & $\begin{array}{l}0.185^{* *} \\
{[0.091]}\end{array}$ & $\begin{array}{c}-0.074^{* *} \\
{[0.034]}\end{array}$ & $\begin{array}{l}0.183 * * * \\
{[0.033]}\end{array}$ \\
\hline Other occupations & $\begin{array}{c}-0.003^{* * *} * \\
{[0.001]}\end{array}$ & $\begin{array}{c}-0.017 * * \\
{[0.008]}\end{array}$ & $\begin{array}{c}-0.052^{* * *} \\
{[0.009]}\end{array}$ & $\begin{array}{c}0.003 \\
{[0.003]}\end{array}$ & $\begin{array}{l}0.297^{* *} \\
{[0.121]}\end{array}$ & $\begin{array}{l}0.139 * * * \\
{[0.041]}\end{array}$ & $\begin{array}{l}0.348^{* * *} \\
{[0.044]}\end{array}$ \\
\hline \multicolumn{8}{|l|}{ Region: } \\
\hline Remainder of South East & $\begin{array}{l}-0.002 \\
{[0.001]}\end{array}$ & $\begin{array}{c}0.008 \\
{[0.009]}\end{array}$ & $\begin{array}{l}0.006 \\
{[0.010]}\end{array}$ & $\begin{array}{c}-0.006^{* * *} \\
{[0.002]}\end{array}$ & $\begin{array}{c}0.014 \\
{[0.087]}\end{array}$ & $\begin{array}{l}0.076 * * \\
{[0.036]}\end{array}$ & $\begin{array}{l}-0.003 \\
{[0.031]}\end{array}$ \\
\hline East Anglia & $\begin{array}{c}-0.003 * * * \\
{[0.001]}\end{array}$ & $\begin{array}{l}-0.014 \\
{[0.011]}\end{array}$ & $\begin{array}{l}0.006 \\
{[0.015]}\end{array}$ & $\begin{array}{l}-0.003 \\
{[0.003]}\end{array}$ & $\begin{array}{l}-0.011 \\
{[0.148]}\end{array}$ & $\begin{array}{l}0.068 \\
{[0.054]}\end{array}$ & $\begin{array}{l}-0.032 \\
{[0.048]}\end{array}$ \\
\hline South West & $\begin{array}{c}-0.002^{* * *} \\
{[0.001]}\end{array}$ & $\begin{array}{c}0.004 \\
{[0.010]}\end{array}$ & $\begin{array}{l}-0.008 \\
{[0.012]}\end{array}$ & $\begin{array}{l}-0.002 \\
{[0.003]}\end{array}$ & $\begin{array}{c}0.104 \\
{[0.113]}\end{array}$ & $\begin{array}{c}0.079 * \\
{[0.044]}\end{array}$ & $\begin{array}{c}0.069 * \\
{[0.039]}\end{array}$ \\
\hline West Midlands & $\begin{array}{c}-0.002^{* *} \\
{[0.001]}\end{array}$ & $\begin{array}{l}-0.008 \\
{[0.010]}\end{array}$ & $\begin{array}{l}-0.018 \\
{[0.011]}\end{array}$ & $\begin{array}{l}-0.004^{*} \\
{[0.002]}\end{array}$ & $\begin{array}{c}0.046 \\
{[0.103]}\end{array}$ & $\begin{array}{l}0.032 \\
{[0.045]}\end{array}$ & $\begin{array}{l}-0.01 \\
{[0.040]}\end{array}$ \\
\hline East Midlands & $\begin{array}{c}-0.002^{* *} \\
{[0.001]}\end{array}$ & $\begin{array}{l}-0.012 \\
{[0.009]}\end{array}$ & $\begin{array}{l}-0.009 \\
{[0.012]}\end{array}$ & $\begin{array}{l}-0.001 \\
{[0.003]}\end{array}$ & $\begin{array}{c}0.056 \\
{[0.121]}\end{array}$ & $\begin{array}{l}0.104^{* *} \\
{[0.044]}\end{array}$ & $\begin{array}{c}0.027 \\
{[0.037]}\end{array}$ \\
\hline Yorkshire \& Humberside & $\begin{array}{l}-0.001 \\
{[0.001]}\end{array}$ & $\begin{array}{c}-0.01 \\
{[0.009]}\end{array}$ & $\begin{array}{l}-0.007 \\
{[0.012]}\end{array}$ & $\begin{array}{l}-0.002 \\
{[0.003]}\end{array}$ & $\begin{array}{c}0.034 \\
{[0.098]}\end{array}$ & $\begin{array}{c}0.064 \\
{[0.044]}\end{array}$ & $\begin{array}{c}0.071 * \\
{[0.039]}\end{array}$ \\
\hline North West & $\begin{array}{l}-0.001 \\
{[0.001]}\end{array}$ & $\begin{array}{l}-0.001 \\
{[0.010]}\end{array}$ & $\begin{array}{l}-0.019 * \\
{[0.011]}\end{array}$ & $\begin{array}{l}-0.004^{*} \\
{[0.002]}\end{array}$ & $\begin{array}{c}0.084 \\
{[0.100]}\end{array}$ & $\begin{array}{l}0.059 \\
{[0.042]}\end{array}$ & $\begin{array}{c}0.035 \\
{[0.036]}\end{array}$ \\
\hline North & $\begin{array}{c}-0.003 * * * \\
{[0.001]}\end{array}$ & $\begin{array}{c}-0.020 * * \\
{[0.009]}\end{array}$ & $\begin{array}{l}0.014 \\
{[0.014]}\end{array}$ & $\begin{array}{l}-0.003 \\
{[0.003]}\end{array}$ & $\begin{array}{l}0.161 \\
{[0.130]}\end{array}$ & $\begin{array}{l}-0.021 \\
{[0.049]}\end{array}$ & $\begin{array}{l}0.007 \\
{[0.041]}\end{array}$ \\
\hline Wales & $\begin{array}{c}-0.003^{* * *} * \\
{[0.001]}\end{array}$ & $\begin{array}{c}-0.022 * * * \\
{[0.008]}\end{array}$ & $\begin{array}{l}-0.002 \\
{[0.011]}\end{array}$ & $\begin{array}{c}-0.005^{* *} \\
{[0.002]}\end{array}$ & $\begin{array}{l}-0.041 \\
{[0.097]}\end{array}$ & $\begin{array}{l}0.116^{* * *} \\
{[0.042]}\end{array}$ & $\begin{array}{c}-0.01 \\
{[0.036]}\end{array}$ \\
\hline Scotland & $\begin{array}{l}-0.001 \\
{[0.001]}\end{array}$ & $\begin{array}{l}-0.007 \\
{[0.008]}\end{array}$ & $\begin{array}{c}-0.021 * * \\
{[0.010]}\end{array}$ & $\begin{array}{l}-0.004 \\
{[0.002]}\end{array}$ & $\begin{array}{c}0.124 \\
{[0.090]}\end{array}$ & $\begin{array}{c}0.072^{*} \\
{[0.039]}\end{array}$ & $\begin{array}{l}-0.007 \\
{[0.033]}\end{array}$ \\
\hline \multicolumn{8}{|l|}{ Other variables: } \\
\hline Log(Minutes commuting to work) & $\begin{array}{c}0.001 \\
{[0.000]}\end{array}$ & $\begin{array}{l}0.007 * * * \\
{[0.002]}\end{array}$ & $\begin{array}{l}0.007 * * \\
{[0.003]}\end{array}$ & $\begin{array}{l}0.002 * * * \\
{[0.001]}\end{array}$ & - & - & - \\
\hline Private Sector & $\begin{array}{l}0.005^{* * *} \\
{[0.001]}\end{array}$ & $\begin{array}{l}0.041 * * * \\
{[0.006]}\end{array}$ & $\begin{array}{c}0.002 \\
{[0.008]}\end{array}$ & $\begin{array}{l}0.005^{* * *} \\
{[0.002]}\end{array}$ & - & - & - \\
\hline Permanent job & $\begin{array}{c}-0.017 * * * \\
{[0.006]}\end{array}$ & $\begin{array}{c}-0.201 * * * \\
{[0.017]}\end{array}$ & $\begin{array}{c}-0.123 * * * \\
{[0.018]}\end{array}$ & $\begin{array}{c}-0.068^{* * *} \\
{[0.012]}\end{array}$ & - & - & - \\
\hline Promotion prospects in primary job & $\begin{array}{c}-0.003^{* * *} * \\
{[0.001]}\end{array}$ & $\begin{array}{c}-0.019 * * * \\
{[0.004]}\end{array}$ & $\begin{array}{c}0.053 * * * \\
{[0.005]}\end{array}$ & $\begin{array}{c}-0.005^{* * *} \\
{[0.001]}\end{array}$ & - & - & - \\
\hline Annual increments & $\begin{array}{c}-0.004^{* * *} \\
{[0.001]}\end{array}$ & $\begin{array}{c}-0.016^{* * *} \\
{[0.004]}\end{array}$ & $\begin{array}{l}-0.006 \\
{[0.005]}\end{array}$ & $\begin{array}{c}-0.004^{* * *} \\
{[0.001]}\end{array}$ & - & - & - \\
\hline Mills Ratio & - & - & - & - & $\begin{array}{l}-0.021 \\
{[0.040]}\end{array}$ & $\begin{array}{l}-0.009 \\
{[0.020]}\end{array}$ & $\begin{array}{c}-0.068^{* * *} \\
{[0.021]}\end{array}$ \\
\hline Predicted probability (linear prediction) & 0.0097 & 0.1236 & 0.1434 & 0.0232 & 0.4536 & 0.4787 & 0.4053 \\
\hline No. of Observations & 22,268 & 25,136 & 25,758 & 22,501 & 485 & 3,367 & 3,989 \\
\hline No. of Individuals & 4,815 & 5,061 & 5,047 & 4,869 & 437 & 2,004 & 2,236 \\
\hline Wald $\chi^{2}$ & $317.7^{* * *}$ & $2,522.7 * * *$ & $1,455.2 * * *$ & $674.2 * * *$ & $1,366^{* * *}$ & $308.5 * * *$ & $398.6^{* * *}$ \\
\hline
\end{tabular}

Notes: ${ }^{*} \mathrm{p}<0.10,{ }^{* *} \mathrm{p}<0.05,{ }^{* * *} \mathrm{p}<0.01$. (A1)-(A4) present marginal effects and standard errors from a random effects probit model. (B1)(B3) show coefficients and bootstrapped standard errors from a linear probability model (based on 1,000 replications). The specifications also include dummy variables for industry $\{17\}$; wave $\{14\}$, and a constant term. 
${ }^{i}$ The distinction is that the term "moonlighting" typically refers to illicitly holding more than one job. For the purposes of this paper the terms "dual job holding" and "moonlighting" will be used interchangeably.

ii A recent European Commission report (2009) estimates that, since the start of the crisis, employment in the EU has shrunk by over 4 million, while by September 2009 the unemployment rate had increased to 9.2 per cent, a rise of 2.5 percentage points compared with spring 2008. Total unemployment in the EU had increased to 22.1 million, a rise of 6.1 million (or more than one-third).

iii For ease of exposition we assume that both individuals carry the same occupational skills (i) from their primary job, so we focus only at the human capital loss from the secondary job when they move to a new primary job in occupation $j$.

iv The derivation of the proposition is provided in Appendix A.

v The BHPS data was made available through the ESRC Data Archive. The data was originally collected by the ESRC Research Centre on Micro-social Change, at the University of Essex. The original collectors of the data, the Data Archive and the affiliated institutions bear no responsibility for the analysis or interpretations presented here.

vi There were some 611 such observations in the sample of dual job holders. A previous version of the paper including these observations rendered very similar results.

vii The creation of the occupational-specific experience variable in the BHPS stems from the detailed work of Zangelidis (2008a). Occupational experience measures the total amount of time an individual has spent in his current occupation from the time he/she first entered the job market. The variable is constructed at the 1-digit level of occupation classification. Part-time and full-time paid employment spells of only salary workers are taken into consideration. The spells of occupational experience do not necessarily have to be continuous. Missing values have been imputed based on a regression model of the length of accumulated occupational-specific experience (available upon request).

viii Heckman (1981) had initially proposed as a solution to the initial conditions problem the specification of a linearized reduced form equation for the initial period. However, this method requires a set of exogenous instruments for identification of the full observed sequence $\left(y_{i 1}, \ldots, y_{i t}\right)$ given $x_{i}$. In contrast, Wooldridge's (2005) suggestion of modeling the density of $\left(y_{i 2}, \ldots, y_{i t}\right)$ conditional on $\left(y_{i 1}, x_{i}\right)$ minimizes both the estimation complexity and the computational cost (Stewart, 2007, p. 516).

ix Other related procedures that have been suggested to tackle the above econometric problem include Kyriazidou (1997) and Dustmann and Rochina-Barrachina (2007). Applications of these methods can also be found in Jones and Labeaga (2003) and Jackle (2007).

x Due to the absence of any theoretical justification, no dynamic terms were used in this model.

xi The joint effect is calculated as a point estimate and standard error of the linear constraint that the summation of the level and the mean effect is equal to zero, for each of the variables in the Mundlak terms separately. The calculated permanent effects are identical to those obtained from a model that incorporates the difference between the yearly and the average values of the independent variables, along with their average values in the specification.

xii Previous research finds that the overtime premium has an ambiguous effect on the probability of moonlighting (Renna, 2006).

xiii Specifications controlling for job security render an insignificant impact on the probability to moonlight (both when included jointly and separately with job satisfaction; available upon request).

xiv An alternative model specification was also employed, where controls for education were not included in the regression to avoid potential collinearity with the occupational variables. No notable changes in effects were observed.

xv For robustness purposes a Probit model and a Random Effects Probit model (with no selection correction) have also been estimated. The results remain fairly similar across the different estimation procedures, so discussion only of the Linear Probability model is provided in the main text. The regression output of the alternative empirical procedures is available from the authors upon request.

xvi In this study, we embark based on the view that occupation codes have the advantage over industry codes of being more closely related to tasks, recognising however that they also have their own problems as a basis for defining specific human capital. This line of analysis is also a necessity based on the lack of available SIC data for moonlighters at the BHPS. Kambourov and Manovskii (2009b) argue that the evidence for industry specific capital is misleading and that 
specificity resides exclusively in occupational categories, with no role for either industry or firm. On the other hand, Neal (1995) and Parent (2000) provide evidence to suggest that industry specificity is much more important than firm specificity. Pavan (2011) argues that the relative roles of industry and occupation remain unclear. Recent studies based on data on job tasks have enabled a more direct approach in the measurement of occupational distance. These newer measures incorporate the fact that different occupations report similar bundles of tasks or skills. The higher the overlap in the task or skill portfolio of two occupations, the more related the occupations are considered to be. Among such measures are those proposed by Poletaev and Robinson (2008), Robinson (2010), Geel and Backes-Gellner (2009), and Gathmann and Schönberg (2010). The generation of data on job tasks for occupations in the United Kingdom and the generation of more specific occupational distance measures provide interesting avenues of future research.

xvii This estimation methodology is considered superior to other alternatives, such as the multinomial probit model. The latter would cater for simultaneous choice between mutually exclusive options. However, that model does not allow the incorporation of individual random effects. Nonetheless, the results and interpretations from the separate four regressions shown in the next section are robust even when using a multinomial probit model (available from the authors upon request).

xviii All estimates can be made available from the authors upon request. Some interesting results emerge from the analysis. Higher job satisfaction reduces the probability to move into self-employment, a new job or a new position. Furthermore, individuals with lengthier accumulated seniority and labour market experience are less likely to exhibit any kind of job mobility. Interestingly, job mobility appears to be a response to the hours-constraints individual face in their primary job. Also, the sector and contract of employment, as well as the promotion and salary prospects, and the travel to work time are estimated to play a significant role in job mobility outcomes.

xix The authors would like to thank an anonymous referee for the comments provided on this issue.

$\mathrm{xx}$ The exclusion restriction variables used for identification are: private sector, permanent job, promotion prospects in primary job, travel to work time and annual increments. Limited evidence of sample selection bias is found, with the inverse Mills ratio negative and significant only for those who get a new position. This suggests that the characteristics that make individuals more likely to get a new position with their current employer makes them less likely also to do a different occupation in that new position.

xxi Due to space limitations we refrain from an extensive discussion of the remaining results, though some findings merit further attention. Individuals with lengthier occupation-specific experience are estimated to be less likely to change occupations in their new primary job. This is a finding that one would expect a priori, since individuals are expected to enjoy larger wage premiums by performing tasks on which they have already accumulated the necessary skills and experience. Also, those with higher seniority in their primary job at period $t$ are more likely to do a different occupation when they get a new job or position at period $t+1$. This may capture the effect of accumulated seniority on the probability of being promoted. Also, higher job satisfaction in the previous primary job are estimated to reduce the probability of changing occupation once a job transition has taken place.

xxii We are grateful to an anonymous referee for this very useful comment.

xxiii Specifically, skilled non-manual occupations comprise of the following SOC codes: 1 (Managers \& administrators), 2 (Professional), 5 (Craft \& related) Skilled manual occupations comprise of the occupations in code 3 (Associate professional \& technical). Unskilled non-manual occupations are those of the codes 4 (Clerical \& secretarial), 6 (Personal $\&$ protective service), 7 (Sales), and unskilled manual are the codes 8 (Plant \& machine operatives) and 9 (Other occupations). 